\title{
$\mathrm{UiO}$ : Det juridiske fakultet
}

\section{Barnets deltakelse i meklinger på familievernkontoret}

Kandidatnummer: 516

Leveringsfrist: 25.11 .2014

Antall ord: 17906 


\section{Innholdsfortegnelse}

1 INNLEDNING .............................................................................................................. 1

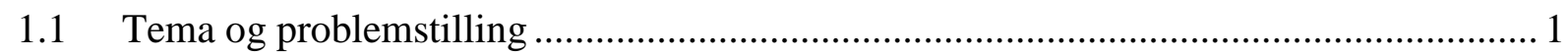

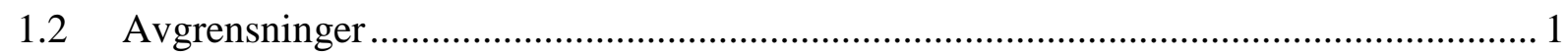

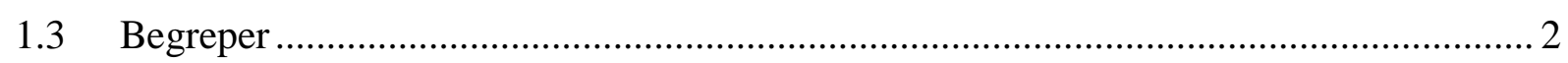

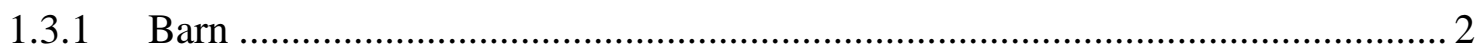

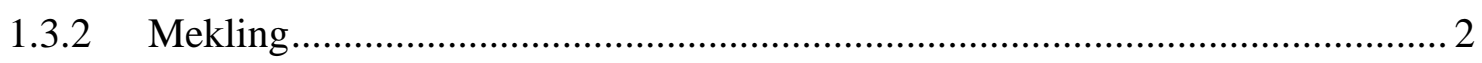

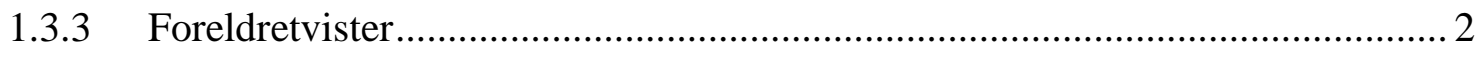

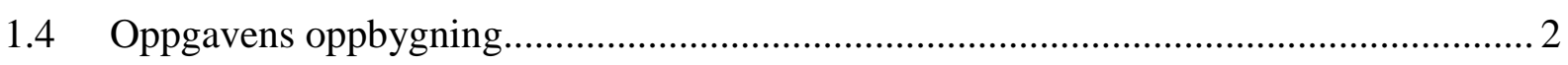

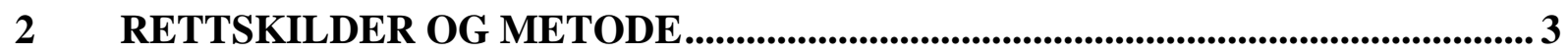

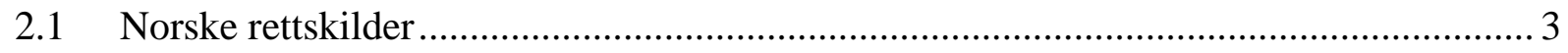

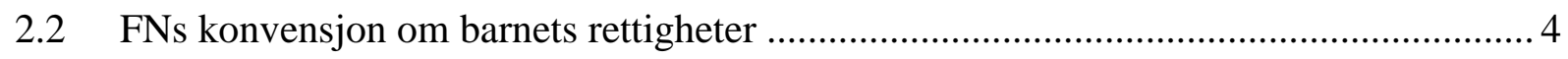

2.2.1 Konvensjonens plass i norsk rett ............................................................ 4

2.2.2 Særlig om uttalelser fra FNs barnekomité ...................................................... 5

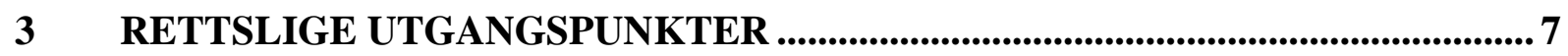

3.1 Generelt om barnelovens saksbehandlingsregler ................................................... 7

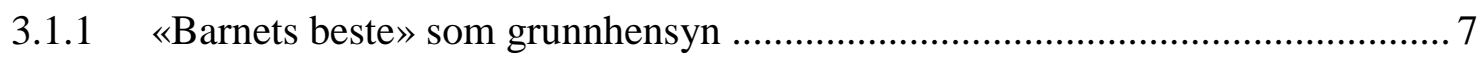

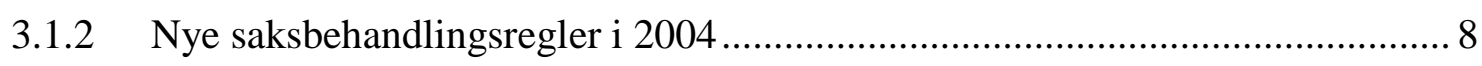

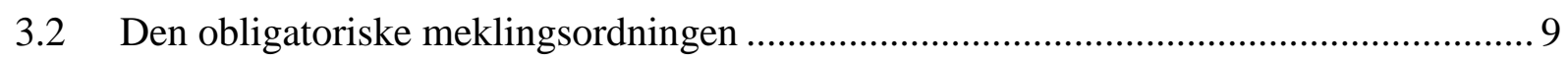

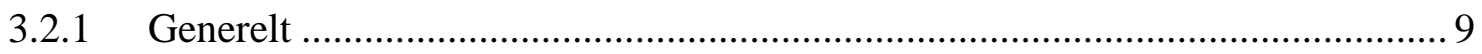

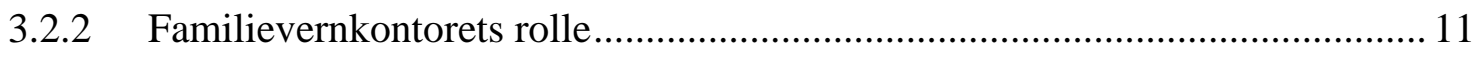

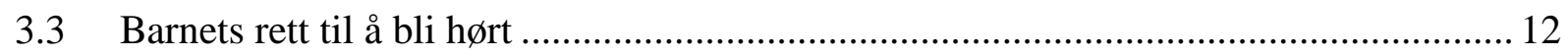

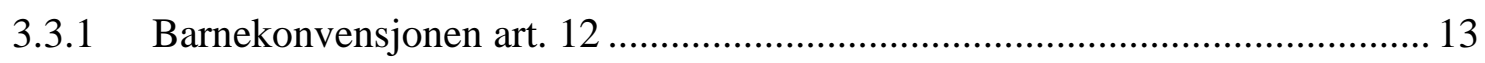

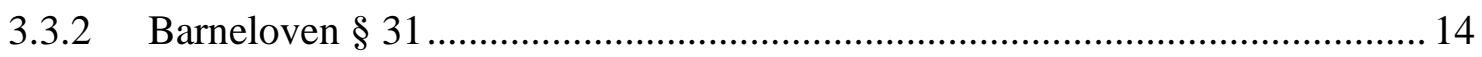

4 BARNETS RETT TIL Å BLI HØRT I MEKLINGEN DE LEGE LATA............. 15

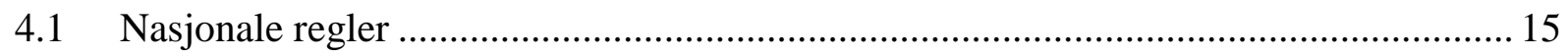

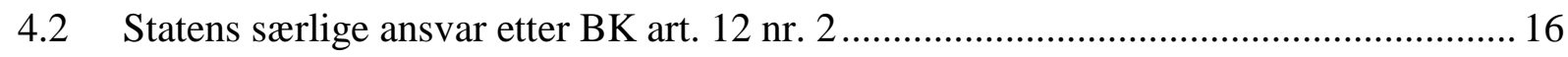

4.3 Er det tilstrekkelig at foreldrene hører barnets mening? .......................................... 17

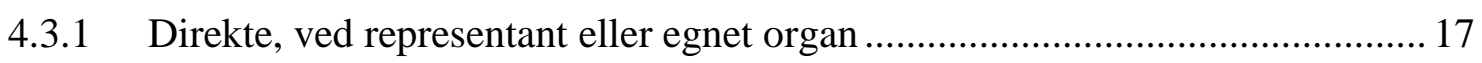

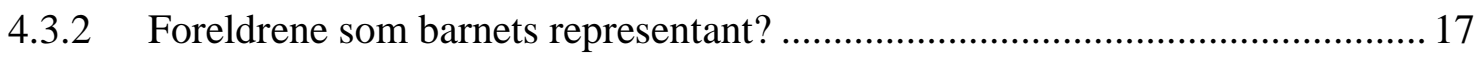

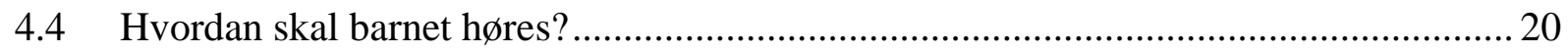

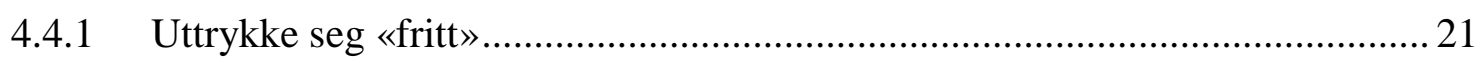

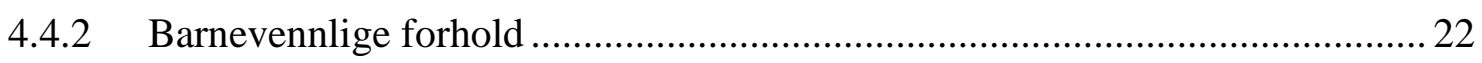

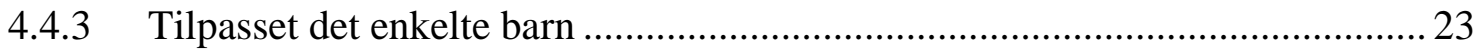




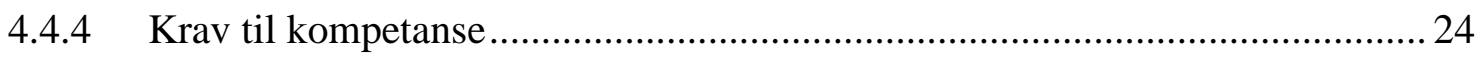

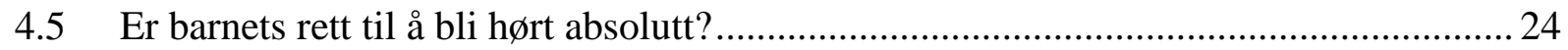

4.6 Er det i strid med BK at foreldrene kan nekte barnet å delta i meklingen? ...................26

4.6.1 Begrepet «rett» og formålet med art. 12 .................................................. 26

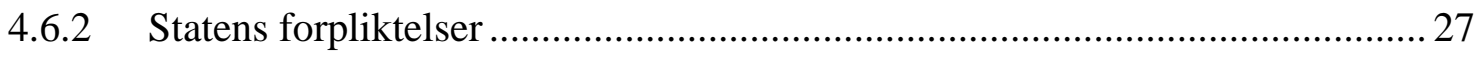

4.6.3 Avsluttende merknader fra barnekomiteen..................................................... 28

5 BARNETS DELTAKELSE I MEKLINGEN I PRAKSIS ....................................30

5.1 I hvilken grad høres barn i forbindelse med meklingen?....................................... 30

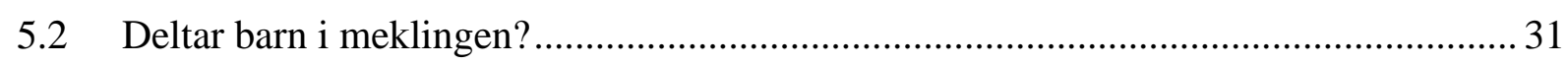

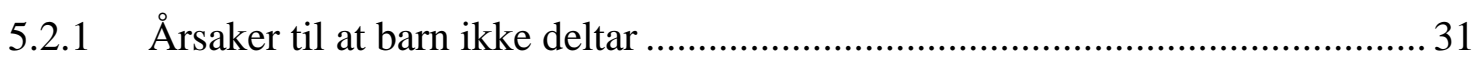

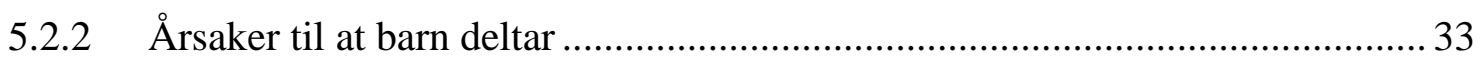

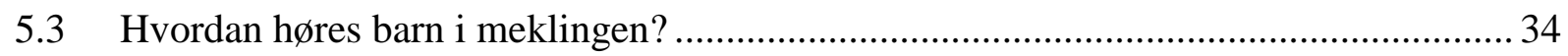

5.4 Erfaringer med og betydningen av barnets deltakelse ........................................... 35

6 RETTSPOLITISKE BETRAKTNINGER OM BARNETS DELTAKELSE I

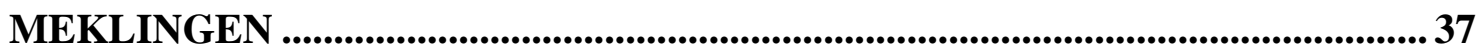

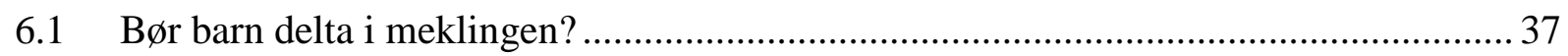

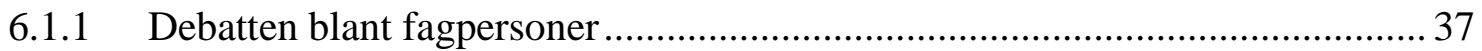

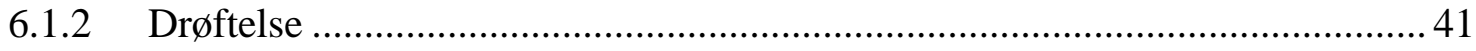

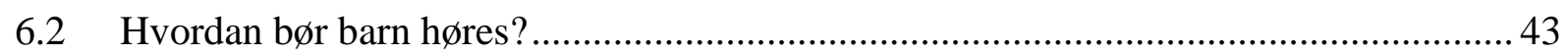

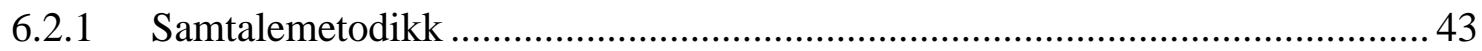

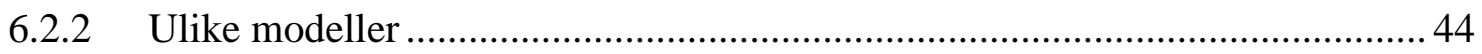

6.3 Hvordan kan meklingsordningen bedre tilrettelegges for barns deltakelse? ................ 46

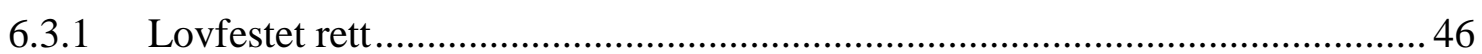

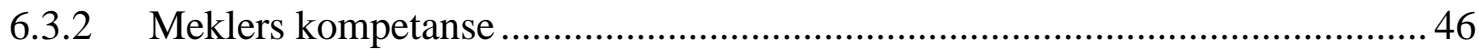

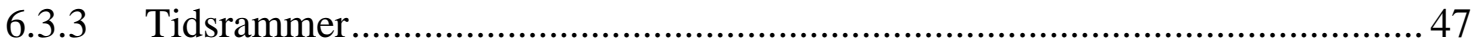

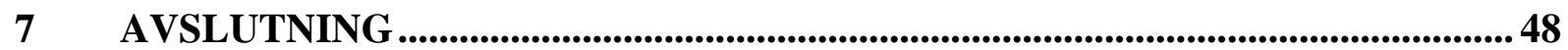

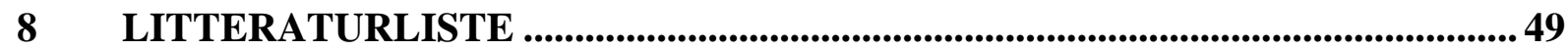




\section{Innledning}

\subsection{Tema og problemstilling}

Temaet for oppgaven er barnets deltakelse i meklinger på familievernkontoret. Etter barneloven $\S 51$ og ekteskapsloven $\S 26$ er det obligatorisk for alle foreldre med felles barn under 16 år å møte til mekling ved separasjon, skilsmisse og samlivsbrudd, og før en tvist om barna kan reises for domstolene. Denne meklingen foretas vanligvis på et offentlig godkjent familievernkontor. Formålet med meklingen er at foreldrene skal få hjelp til å komme fram til en avtale om foreldreansvar, hvor barnet skal bo fast og om samvær, jf. barneloven $\S 52$. Avtalen skal være til det beste for barnet, jf. barneloven 48 og barnekonvensjonen art. 3. Etter både norske og internasjonale regler har barn rett til å få si sin mening før det tas avgjørelser i slike saker, jf. barneloven $\S 31$ og barnekonvensjonen art. 12. Dersom saken bringes inn for domstolene, har dommeren et lovpålagt ansvar for å ivareta barnets rett til å bli hørt. I forbindelse med meklingen er det derimot ikke konkretisert hvordan retten skal ivaretas. Foreldrene er gitt ansvaret for å høre barnet, og barnet har ingen selvstendig rett til å delta i meklingen. Dette er blant annet begrunnet med at det er foreldrene som skal ta avgjørelsen om barna. Samtidig er det offentlige ansvarlige for meklingsordningen. I norsk sammenheng har det derfor blitt reist spørsmål ved om meklingsordningen i tilstrekkelig grad ivaretar barnets rett til å bli hørt, og dette vil være oppgavens hovedproblemstilling.

\subsection{Avgrensninger}

Mekling som konfliktløsningsmetode har fått en mye større plass med den nye tvisteloven av 2005 og barnelovens nye saksbehandlingsregler i 2004, både i og utenfor domstolene. Denne oppgaven avgrenser mot alle former for mekling som foretas etter at sak er reist for domstolene, jf. barneloven $\S 61$. Dette fordi dommeren da har et lovpålagt ansvar for å ivareta barnets rett til å bli hørt, noe meklere utenfor domstolene ikke har i tilsvarende grad.

Barnets rett til å bli hørt er ikke den eneste problemstillingen som reiser seg i forbindelse med mekling i saker etter barneloven. Jeg vil i oppgaven ikke drøfte $\varnothing$ vrige problemstillinger knyttet til meklingsordningen, som i hvilke saker mekling er egnet som konfliktløsningsmetode og ikke, om mekling er til barnets beste, og foreldrenes perspektiv. Dette fordi meklingen er obligatorisk etter barneloven $\S 51$, samtidig som det mangler klare regler for ivaretakelsen av barnets rett til å bli hørt.

Videre vil jeg fokusere på meklingen som gjennomføres på familievernkontorene, og ikke av eksterne meklere. Dette fordi det er vanligst at meklingen foretas på familievernkontorene, og det er derfor her det er mest relevant å se på barnets deltakelse. 


\subsection{Begreper}

\subsubsection{Barn}

Begrepet «barn» vil jeg bruke som betegnelse på alle personer under 18 år, med mindre noe annet er presisert. Dette er i samsvar med barnekonvensjonen art. 1, og er også den vanlige bruken av begrepet i juridisk terminologi. ${ }^{1}$

\subsubsection{Mekling}

Mekling er ikke et entydig begrep, og det kan defineres på forskjellige måter. En definisjon som går igjen i ulike tradisjoner er imidlertid følgende: «Mekling er en uformell prosess der en upartisk tredjeperson hjelper partene til å komme frem til en gjensidig akseptabel løsning på konflikten. Mekleren har ingen autoritet til å fastsette løsningen». ${ }^{2}$

\subsubsection{Foreldretvister}

Jeg vil bruke begrepet «foreldretvister» som fellesbetegnelse på saker om foreldreansvar, fast bosted og samvær som bringes inn for domstolene. ${ }^{3}$ I dagligtale og juridisk teori omtales disse sakene også som barnefordelingssaker.

\subsection{Oppgavens oppbygning}

Oppgaven har til formål å analysere rettskildesituasjonen de lege lata, se på hvordan reglene praktiseres, samt foreta rettspolitiske betraktninger av reglene. Jeg har valgt å dele oppgaven inn i fem hoveddeler, der pkt. 2 og 3 er mer innledende deler, mens drøftelsene blir gjennomført i pkt. 4-6.

Etter en gjennomgang av rettskildebildet og metoden i oppgaven (pkt. 2), vil jeg presentere rettsreglene som danner utgangspunkt for oppgaven (pkt. 3). Jeg vil deretter drøfte barnets rett til å bli hørt i meklingen de lege lata (pkt. 4), ved å tolke de nasjonale reglene og barnekonvensjonens regler. I pkt. 5 vil jeg presentere ulike unders $\varnothing$ kelser som er gjort om høring av barn i meklingen, for å se hvordan de gjeldende reglene gir seg utslag i praksis. Til slutt vil jeg i pkt. 6 foreta noen rettspolitiske betraktninger om barnets deltakelse i meklingen, med utgangspunkt i den rettsdogmatiske analysen i pkt. 4 og praktiseringen av reglene i pkt. 5.

\footnotetext{
${ }^{1}$ Smith (2006) s. 24

${ }^{2}$ Nordhelle (2006) s. 22

${ }^{3}$ Prop.85 L (2012-2013) s. 6
} 


\section{Rettskilder og metode}

Rettskildene og metoden i oppgaven skiller seg noe fra den tradisjonelle juridiske metoden. Dette skyldes flere forhold. For det første handler oppgaven om saksbehandlingsregler utenfor domstolene. Dette gjør at rettspraksis vil bli mindre brukt enn ellers, mens andre rettskilder får en mer sentral betydning. For det andre er barnets rett til å bli hørt hjemlet både i norske og internasjonale regler. Internasjonale rettskilder og tolkningsprinsipper vil derfor spille en rolle ved siden av de norske. For det tredje er barnets deltakelse i meklingen et tema som også har sider til andre fagfelt enn jussen, særlig psykologi. Dette gjør at reelle hensyn vil stå noe mer sentralt enn ellers. På grunn av disse forholdene, vil jeg redegjøre noe nærmere for rettskildene i oppgaven.

\subsection{Norske rettskilder}

Den mest sentrale norske loven som vil bli brukt i oppgaven er lov om barn og foreldre av 1981 (heretter barneloven, bl). Reglene om mekling er hjemlet i $\S 51-54$, mens barnets rett til å bli hørt fremgår av $\S 31$.

Reglene om mekling er nærmere utdypet i forskrift om mekling etter ekteskapsloven og barneloven av. 18.12.2006 nr. 1478 (heretter meklingsforskriften). Forskriften er gitt av Barne-, likestillings- og inkluderingsdepartementet med hjemmel i ekteskapsloven $§ 26$ og barneloven $\S 51(4)$. Selv om forskrifter er fastsatt av forvaltningen og ikke er formelle lover, regnes de som lovgivning i vid forstand. ${ }^{4}$ De tolkes derfor på samme måte som andre lover.

Ved tolkningen av barnelovens saksbehandlingsregler vil særlig forarbeider stå sentralt. Dette fordi reglene har blitt endret en rekke ganger etter at loven ble vedtatt. Både NOU, Ot.prp., Prop. L og Innst.O vil være relevante.

Til meklingsforskriften er det utarbeidet et rundskriv fra Barne- og likestillingdepartementetrundskriv Q-02/2008. Rundskrivet angir departementets retningslinjer for anvendelse av forskriften. ${ }^{5}$ Departementet har også utgitt flere veiledere og brosjyrer om samlivsbrudd og samtaler med barn. I tillegg foreligger det en stortingsmelding som behandler temaet - St.meld.nr. 29 (2002-2003). Grunnen til at det er så mange politiske føringer på området, er at barns rettigheter i de senere årene har fått et $\varnothing \mathrm{kt}$ fokus i samfunnet.

\footnotetext{
${ }^{4}$ Andenæs (2009) s. 13

${ }^{5}$ Rundskriv Q-02/2008 s. 1
} 
I rettskildelæren blir rundskriv og veiledninger fra departementene regnet som rettsoppfatninger, mens stortingsmeldinger blir ansett som etterarbeider til loven. ${ }^{6}$ Ingen av disse dokumentene tilhører de autoritative rettskildene. På grunn av det politiske aspektet, foreligger det debatt i rettskildelæren om hvilken vekt de kan tillegges når man skal fastlegge gjeldende rett. ${ }^{7}$ Jeg vil derfor kun bruke de som tolkningsmomenter i oppgaven, uten å fastlegge gjeldende rett utelukkende på grunnlag av disse.

Juridisk teori og reelle hensyn vil også bli trukket inn, særlig om rettstilstanden er uklar og det er få andre rettskilder å se hen til. Argumentene fra teorien kan ha argumentasjonsverdi, mens de reelle hensynene vil være relevante for å vurdere hvor godt resultatet er. ${ }^{8}$ Dette er særlig viktig på et felt som barneretten, hvor det er mange skjønnsmessige vurderinger av hva som er til barnets beste, og store verdier som står på spill.

Videre vil statistikk, tidligere undersøkelser og forskning være relevant for å illustrere praktiseringen av reglene, samt i den rettspolitiske delen.

\subsection{FNs konvensjon om barnets rettigheter}

Den mest sentrale internasjonale rettskilden i oppgaven er FNs konvensjon om barnets rettigheter av 1989 (heretter barnekonvensjonen, BK). Artikkel 12 hjemler barnets rett til å bli hørt, men også enkelte andre artikler vil bli trukket inn. Ettersom retten til å bli hørt er hjemlet både i norsk og internasjonal rett, finner jeg det hensiktsmessig å si noe om konvensjonens plass i norsk rett og tolkningen av den.

\subsubsection{Konvensjonens plass i norsk rett}

Barnekonvensjonen ble vedtatt av FN i 1989 og ratifisert av Norge i 1991. At det er en konvensjon, og ikke en erklæring, gjør at den er rettslig bindende for statene som ratifiserer den. ${ }^{9}$ Norge har derfor vært folkerettslig forpliktet av konvensjonen siden $1991 .{ }^{10}$ I 2003 ble barnekonvensjonen inkorporert direkte i norsk lov gjennom menneskerettsloven $\S 2 \mathrm{nr} .4,{ }^{11}$ og skal gå foran andre lover ved motstrid, jf. menneskerettsloven $\S 3$. Inkorporeringen medførte også at konvensjonen ble innarbeidet i norsk lovgivning for $\emptyset v$ vrig, for å synliggjøre bestemmelsene

\footnotetext{
${ }^{6}$ Boe (2012) s. 279, 236

${ }^{7}$ Boe (2012) s. 279 flg, 223 flg.

${ }^{8}$ Andenæs (2009) s. 118, Eckhoff (2001) s. 371

${ }^{9}$ Smith (2012) s. 17

${ }^{10}$ Holgersen (2008) s. 53

${ }^{11}$ Lov om endringer i menneskerettsloven mv. av 01.08.2003 nr. 86
} 
og sikre at de blir etterlevd i praksis. ${ }^{12}$ Barnekonvensjonen har dermed fătt en sterk stilling i norsk rett. ${ }^{13}$

På de fleste av konvensjonens områder har Norge gitt mer presise nasjonale rettsregler. Der slike regler finnes, er det $\mathrm{i}$ hovedsak disse som vil bli anvendt av forvaltningen og domstolene. Barnekonvensjonens regler vil først være aktuelle å bruke direkte hvis de påstås å gi barnet større rettigheter enn det som følger av nasjonal lovgivning. ${ }^{14}$ Direkte anvendelse av barnekonvensjonen kan imidlertid by på tolkningsproblemer i enkelte tilfeller, fordi noen av artiklene bare er rettet mot statsmyndighetene, eller er så vage at de etter sitt innhold er dårlig egnet som selvstendig rettsgrunnlag. ${ }^{15}$ Artikkel 12 om barnets rett til å bli hørt er imidlertid konkret nok til å bli anvendt direkte. ${ }^{16}$

Når barnekonvensjonen er gjort til norsk lov, vil de alminnelige prinsippene for traktattolkning erstatte norske lovtolkningsprinsipper ved tolkning av konvensjonen. ${ }^{17}$ Utgangspunktet er da den naturlige forståelsen av konvensjonsteksten. Denne må tolkes i lys av konvensjonens gjenstand og formål, jf. Wien-konvensjonen art. 31(1). Videre må konvensjonen tolkes som en helhet, noe barnekomiteen også legger stor vekt på. ${ }^{18}$

\subsubsection{Særlig om uttalelser fra FNs barnekomité}

Ved tolkningen av barnekonvensjonen står særlig uttalelser fra FNs barnekomité sentralt ved siden av de alminnelige tolkningsprinsippene. FNs barnekomité er en ekspertkomité med 18 sakkyndige som har til oppgave å overvåke konvensjonen, jf. BK art. 43 nr. 1 og 2. Overvåkningen foregår ved at statene hvert femte år plikter å sende inn rapporter til komiteen om sin nasjonale gjennomføring av konvensjonen, jf. BK art. 44. På bakgrunn av disse rapportene, samt diskusjoner med statene, skriver barnekomiteen sine bekymringer og anbefalinger til statene, kalt avsluttende merknader («concluding observations»). Disse er ikke rettslig bindende, og det er ingen sanksjoner dersom de ikke blir fulgt. ${ }^{19}$ Det er imidlertid enighet i teorien om at de har betydning som tolkningsfaktor, til tross for manglende formell status. ${ }^{20}$

\footnotetext{
${ }^{12}$ Ot.prp.nr. 45 (2002-2003) s. 24, 26, Innst.O.nr. 92 (2002-2003)

${ }^{13}$ Smith (2012) s. 27

${ }^{14}$ Smith (2012) s. 28

${ }^{15}$ Smith (2012) s. 24, Rt-2001-1006 s. 1015

${ }^{16}$ Smith (2012) s. 24

17 Andenæs (2009) s. 60

${ }^{18}$ Smith (2012) s. 25

${ }^{19}$ Smith (2012) s. 22-23

${ }^{20}$ Søvig (2009) s. 35
} 
Barnekomiteen utgir også generelle kommentarer ( «general comments») med sine tolkninger av enkelte artikler i konvensjonen eller særlig viktige spørsmål. ${ }^{21}$ Heller ikke disse er rettslig bindende, men de antas å ha betydelig vekt ved tolkningen av konvensjonen. ${ }^{22}$ Dette fordi de avgis av det internasjonale organet som er oppnevnt for å overvåke konvensjonen, de baserer seg på komiteens praksis og er gjennomarbeidet. ${ }^{23}$ De fleste av kommentarene blir til i samarbeid med UNICEF og andre organisasjoner etter en meget bred høringsprosess. ${ }^{24}$ Søvig presiserer for $\varnothing v$ vrig at en uttalelse $i$ en generell kommentar har større gjennomslagskraft jo mer utfyllende argumentasjonen er, og jo mer spesifikt den tar opp tematikken som prøves. ${ }^{25}$ Også domstolene trekker i stadig større grad frem uttalelser fra barnekomiteen. ${ }^{26}$ I Rt. 2001 s. 1006 uttalte for eksempel Høyesterett at uttalelsene er av «interesse». ${ }^{27}$

De sentrale generelle kommentarene i denne oppgaven er General Comment No 12 (2009) om barnets rett til å bli hørt, og General Comment No. 5 (2003) om generelle tiltak til gjennomføring av konvensjonen.

\footnotetext{
${ }^{21}$ Smith (2012) s. 25

${ }^{22}$ Smith (2012) s. 25, Sandberg (2012) s. 91, Søvig (2009) s. 37

${ }^{23}$ Sandberg (2012) s. 91

${ }^{24}$ Smith (2012) s. 25

${ }^{25}$ Søvig (2009) s. 37

${ }^{26}$ Smith (2012) s. 25, 27

${ }^{27}$ Rt-2001-1006 s. 1016
} 


\section{Rettslige utgangspunkter}

\subsection{Generelt om barnelovens saksbehandlingsregler}

Barneloven er en av mange lover som regulerer barns rettsstilling i samfunnet. Den omhandler de familierettslige spørsmålene om foreldreskap og rettigheter og plikter i forholdet mellom barn og foreldre, og er derfor en privatrettslig lov. Loven gjelder for alle barn uavhengig av foreldrenes sivilstatus. ${ }^{28}$

Det er sjelden at forholdet mellom barn og foreldre i det daglige er preget av rettslige reguleringer. Ett unntak er imidlertid når foreldrene skiller lag. ${ }^{29}$ Foreldrene må da ta stilling til hvem som skal ha foreldreansvaret, hvor barnet skal bo fast og hvordan samværsordningen skal være med den av foreldrene barnet ikke bor hos. Barnelovens utgangspunkt er at foreldrene kan avtale de ordningene de selv $\emptyset$ nsker, jf. bl. §§ 34-36 og 43. Dette fordi det forutsettes at foreldrene normalt er i stand til å finne fram til den beste løsningen for barna. ${ }^{30}$ Dersom foreldrene ikke kommer til enighet, skal imidlertid tvisten avgjøres av domstolene, jf. bl. § 56 . Foreldrene blir da sakens parter, mens barnet er den tvisten gjelder. At tvisten angår en person som selv formelt står utenfor saken, er et særtrekk ved slike saker. ${ }^{31}$ I tillegg er de følelsesmessige sidene ofte sterke, saken kan være en stor belastning for både barnet og foreldrene, og utfallet er av sentral betydning. Dette gjør at sakene skiller seg fra andre sivile saker, og skaper særlige utfordringer i forhold til saksbehandlingen og barnets rolle. ${ }^{32}$

\subsection{1 «Barnets beste» som grunnhensyn}

Et grunnleggende hensyn i alle saker som angår barn, er hensynet til «barnets beste». Dette er hjemlet både i BK art. 3 og i en rekke nasjonale lover. I 2014 ble hensynet også grunnlovsfestet i grl. § 104(2).

Barnekomiteen har omtalt BK art. 3 som ett av konvensjonens fire generelle prinsipper. ${ }^{33}$ Dette innebærer at det både er et selvstendig prinsipp, samtidig som det skal tillegges betydning ved tolkningen og anvendelsen av alle de andre bestemmelsene. ${ }^{34}$ Barnets beste gjennomsyrer dermed hele barneretten.

\footnotetext{
${ }^{28}$ Smith (2006) s. 19-20

${ }^{29}$ Smith (2006) s. 21-22

${ }^{30}$ Haugli (2012) s. 62

${ }^{31}$ Ot.prp.nr. 29 (2002-2003) s. 7, NOU 1998:17 s. 16

${ }^{32}$ Smith (2006) s. 132

${ }^{33}$ General Comment No. 5 pkt. 12

${ }^{34}$ Smith (2012) s. 19
} 
I barneloven er hensynet hjemlet i $\S 48$, som angir barnets beste som overordnet norm. ${ }^{35} \mathrm{Be}$ stemmelsen presiserer videre at både selve avgjørelsen og saksbehandlingen skal være til barnets beste. Hensynet skal dermed ivaretas på alle stadier av konflikten mellom foreldrene, og av alle som har befatning med slike saker, blant annet dommere, advokater, sakkyndige og meklere. ${ }^{36}$

Hva som nærmere ligger i uttrykket «barnets beste», er imidlertid ikke definert hverken i barnekonvensjonen eller de nasjonale reglene. Ideen bak BK art. 3 er at man skal ta utgangspunkt i det enkelte barns behov og forutsetninger. ${ }^{37}$ I forhold til bl. $\S 48$ har departementet uttalt at de finner det vanskelig å definere barnets beste i loven, og at det bør bero på en «konkret individuell vurdering i hver sak». ${ }^{38}$ De viser videre til at det i rettspraksis er trukket opp retningslinjer for momenter som er sentrale i vurderingen av de materielle avgjørelsene. ${ }^{39}$ Dette har blitt gjort i en rekke høyesterettsdommer, blant annet i Rt. 2005 s. 682, som gjaldt spørsmål om fast bosted og samværsrett for en jente på 10 år. De sentrale momentene som ble vurdert her, var risikoen ved miljøskifte, hensynet til å sikre best mulig samlet foreldrekontakt, kontakt med søsken, stabilitet i tilværelsen, foreldrenes personlige egenskaper, barnets tilknytning til foreldrene, og barnets $\emptyset$ nsker. ${ }^{40}$ Hva som er «barnets beste» vil derfor bero på en konkret helhetsvurdering, noe som også er lagt til grunn i teorien. ${ }^{41}$ Denne vurderingen krever både psykologisk innsikt, kunnskap om barn og stor grad av skjønn, og skiller seg derfor fra andre rettslige vurderinger. ${ }^{42}$ Hva det innebærer at saksbehandlingen skal rette seg etter barnets beste, vil bli redegjort nærmere for i neste avsnitt.

\subsubsection{Nye saksbehandlingsregler i 2004}

I april 2004 fikk barneloven et nytt kapittel 7 med saksbehandlingsregler i foreldretvister. Det var flere grunner til dette. Tidligere var reglene spredt i tvistemålsloven, domstolloven, ekteskapsloven og barneloven, i tillegg til flere forskrifter. I det nye kapitlet er de viktigste reglene samordnet, for at de skal være enklere og mer oversiktlige å finne fram til, både for foreldre og jurister. Fortsatt må reglene suppleres noe av domstolloven og tvistelovens alminnelige regler, jf. bl. § 59(3), samt enkelte forskriftsbestemmelser, men i langt mindre grad enn tidligere. $^{43}$

\footnotetext{
${ }^{35}$ Ot.prp.nr. 29 (2002-2003) s. 26

${ }^{36}$ Kjølberg (2006) s. 19, NOU 1998:17 s. 40, Haugli (2012) s. 62

${ }^{37}$ Haugli (2012) s. 53

${ }^{38}$ Ot.prp.nr. 29 (2002-2003) s. 28

${ }^{39}$ Ot.prp.nr. 29 (2002-2003) s. 28

${ }^{40}$ Rt-2005-682 avsn. 32-42

${ }^{41}$ Smith (2006) s. 140, Haugli (2012) s. 65, Kjølberg (2006) s. 19

${ }^{42}$ NOU 1998:17 s. 16

${ }^{43}$ NOU 1998:17 s. 40, Ot.prp.nr. 29 (2002-2003) s. 26
} 
I det nye kapitlet $\emptyset$ nsket lovgiver å slå fast prinsippet om barnets beste innledningsvis, jf. § 48. Tidligere fremkom hensynet av ulike bestemmelser i loven. Ett av formålene med den nye bestemmelsen, var å presisere at barnets beste ikke bare skal ivaretas i selve avgjørelsen, men også i hele prosessen frem mot den. Dette samsvarer med BK art. $3{ }^{44}$

For å sikre at prosessen faktisk ivaretar barnets beste, ble det også vedtatt en rekke nye saksbehandlingsregler som bare gjelder for saker etter barneloven. Tidligere ble sakene behandlet etter samme prosessregler som andre sivile saker, men dette har vært kritisert. Det har blant annet vært hevdet at domstolsbehandlingen bidrar til å forsterke konflikten mellom foreldrene, og at de spesielle behovene i sakene krever særlige regler. ${ }^{45}$ I det nye kapitlet har lovgiver bygget på det syn at en avtaleløsning mellom foreldrene er det beste for barnet i de fleste tilfeller, da dette kan bidra til å dempe konflikten, og gi bedre mulighet for at avtalen respekteres av foreldrene. Reglene har derfor som hovedformål å legge til rette for at foreldrene kan komme til enighet om barna. ${ }^{46}$ I tillegg $\varnothing$ nsket lovgiver mer fleksible saksbehandlingsregler, slik at prosessen kan tilpasses den enkelte sak. ${ }^{47}$

Dette har medført at dommeren er gitt flere valgmuligheter for hvordan de ulike sakene kan behandles, og flere virkemidler som legger til rette for avtalebaserte løsninger. Blant annet er det innført utvidet adgang til bruk av sakkyndig, og mekling har fått en mye større plass enn tidligere. ${ }^{48}$ På et hvert trinn av saken skal dommeren vurdere om det er mulig å oppnå forlik, og legge til rette for dette, jf. bl. § 59(2). Dommeren kan selv foreta mekling mellom partene under saksforberedelsen, jf. bl. § 61(1). Også i den nye tvisteloven av 2005 spiller mekling en mye større rolle enn tidligere.

\subsection{Den obligatoriske meklingsordningen}

\subsubsection{Generelt}

Mekling har ikke bare en sentral plass i domstolene, men også utenfor. Den obligatoriske meklingsordningen for foreldre med felles barn under 16 år som skal skille lag, ble innført allerede i $1993 .{ }^{49}$ Reglene har imidlertid blitt endret en rekke ganger, og står nå i barnelovens

\footnotetext{
${ }^{44}$ NOU 1998:17 s. 40, 38, Ot.prp.nr. 29 (2002-2003) s. 26

${ }^{45}$ NOU 1998:17 s. 45

${ }^{46}$ NOU 1998:17 s. 40, Ot.prp.nr. 29 (2002-2003) s. 7

${ }^{47}$ NOU 1998:17 s. 45

${ }^{48}$ NOU 1998:17 s. 45

${ }^{49}$ NOU 1998:17 s. 29
} 
kapittel 7, §§ 51-54. Også denne meklingsordningen kom som en følge av at avtaleløsning mellom foreldrene er å foretrekke i de fleste tilfeller. ${ }^{50}$

Etter bl. $\S 51$ er det obligatorisk for alle foreldre med felles barn under 16 år å møte til mekling i to ulike situasjoner. For det første må foreldrene møte til mekling ved separasjon, skilsmisse og samlivsbrudd. Meklingen er da et vilkår for at gifte foreldre skal få separasjons- og skilsmissebevilling, jf. ekteskapsloven $§ 26(1)$, og for at samboere skal kunne få rett til utvidet barnetrygd, jf. barnetrygdloven $\S 9(5)$. Tidligere var det frivillig for samboere å møte til mekling ved samlivsbrudd, men det ble i 2007 gjort obligatorisk også for disse for å likestille alle barn uavhengig av foreldrenes sivilstatus. ${ }^{51}$

For det andre må foreldrene møte til mekling før de kan reise sak for domstolene om foreldreansvar, hvor barnet skal bo fast eller om samvær. Dette gjelder uavhengig av om saken reises $i$ forbindelse med at de skal skille lag eller ikke. Meklingen er da en absolutt prosessforutsetning, slik at saken skal avvises dersom meklingen ikke er gjennomført, jf. bl. § 56(2). ${ }^{52}$

Formålet med meklingen er i alle tilfeller at foreldrene skal få hjelp til å komme fram til en skriftlig avtale om foreldreansvaret, hvor barnet skal bo fast og om samvær, jf. bl. § 52. Avtalen skal rette seg etter det som er til barnets beste, og mekler skal ha fokus på dette, jf. meklingsforskriften $\S 2$, bl. $\S 48$ og BK art. 3. Meklingsordningen ivaretar derfor et samfunnsmessig ansvar for barnets beste, noe som blant annet er begrunnet med at foreldre ikke alltid er i stand til å se saken fra barnas perspektiv. ${ }^{53}$ Imidlertid er det foreldrene selv som er ansvarlige for innholdet $\mathrm{i}$ avtalen de eventuelt kommer fram til, og ikke mekler. ${ }^{54}$

Meklers rolle er først og fremst å bidra til at foreldrene har det nødvendige grunnlaget for å komme fram til en avtale. ${ }^{55}$ De skal blant annet gi foreldrene informasjon om de viktigste $\emptyset$ konomiske konsekvensene avtalen vil medføre, relevante regler i barneloven og annet regelverk, samt bidra med kunnskap om barn og foreldrenes reaksjoner i forbindelse med samlivsbrudd. ${ }^{56}$ Departementet har også utarbeidet brosjyren «Mekling for foreldre», som gir nyttig informasjon til foreldrene. ${ }^{57}$

\footnotetext{
${ }^{50}$ NOU 1998:17 s. 40

${ }^{51}$ Ot.prp.nr. 103 (2004-2005) s. 19

${ }^{52}$ Ot.prp.nr. 103 (2004-2005) s. 19

${ }^{53}$ Ot.prp.nr. 28 (1990-1991) s. 37-38, Innst.O.nr. 71 (1990-1991) s. 6, Haugen (2010) s. 120

${ }^{54}$ Meklingsforskriften $§ 1(5)$, Rundskriv Q-02/2008 s. 6

${ }^{55}$ Rundskriv Q-02/2008 s. 4

${ }^{56} \mathrm{Bl}$. § 52, meklingsforskriften § 1(2), Rundskriv Q-02/2008 s. 4

${ }^{57}$ Brosjyre Q-0795
} 
Det er obligatorisk for foreldrene å møte til en time mekling, jf. bl. § 54. Dette gjelder også foreldre som er enige på forhånd. ${ }^{58}$ Etter denne timen blir det utstedt meklingsattest, uavhengig av om foreldrene har kommet fram til en avtale eller ikke, jf. bl. $\S 54 .^{59}$ Dersom foreldrene ikke har blitt enige, skal imidlertid mekler oppfordre foreldrene til å mekle i inntil tre timer til, jf. bl. § 54. Dersom mekler ser det som mulig at ytterligere mekling kan føre fram til en avtale, kan de tilbys enda tre timer. Det totale tilbudet er derfor på 7 timer, men all mekling utover den obligatoriske timen er frivillig for foreldrene, og forutsetter at begge foreldrene $\emptyset$ nsker å benytte seg av tilbudet. ${ }^{60}$

Før 2007 var det obligatorisk med tre timer mekling, med mindre partene kom til enighet tidligere, mens det totale tilbudet var på fire timer. ${ }^{61}$ Grunnen til at de obligatoriske timene ble senket og det frivillige tilbudet $\varnothing \mathrm{kt}$, var at lovgiver $\emptyset$ nsket å styrke meklingsordningen ved å skreddersy den inn mot de par som trenger det mest. Ved å gjøre ordningen mer fleksibel, kan det brukes mer tid på sakene med størst konflikt, og mindre tid på de andre. ${ }^{62}$ Nå diskuteres det imidlertid igjen om de nye tidsrammene er tilfredsstillende. ${ }^{63}$

\subsubsection{Familievernkontorets rolle}

Den obligatoriske meklingen skal foretas enten ved et familievernkontor eller hos en ekstern mekler, jf. meklingsforskriften § 4. Alle meklere må være godkjent av Barne-, ungdoms-, og familieetaten (Bufetat), jf. meklingsforskriften $\S 3$. For å bli godkjent må de ha gjennomført opplæring som sikrer de gode kunnskaper om voksnes og barns reaksjoner i og etter samlivsbrudd, og gjør de godt orientert om relevante faglige og juridiske spørsmål. Hva slags opplæring som skal gjennomføres for å oppfylle disse kravene, er opp til Bufetat å avgjøre, jf. meklingsforskriften $\S 4$. Bufetat har ansvaret for å sikre at det finnes et kvalifisert meklingsapparat som er geografisk tilgjengelig for alle, at ventetiden ikke er for lang, og at brukerne skal ha en viss valgmulighet med hensyn til mekler, jf. meklingsforskriften $\S 3$. Bufetat er underlagt Barne- og likestillingsdepartementet, og meklingen er derfor en ordning i statlig regi. ${ }^{64}$

\footnotetext{
${ }^{58}$ Rundskriv Q-02/2008 s. 1

${ }^{59}$ Ot.prp.nr. 103 (2004-2005) s. 57 (Til § 54)

${ }^{60}$ Rundskriv Q-02/2008 s. 5

${ }^{61}$ NOU 1998:17 s. 29

${ }^{62}$ Ot.prp.nr. 103 (2004-2005) s. 18

${ }^{63}$ Bla. Barneombudet (2012) s. 33

${ }^{64}$ Bufetat, Presentasjonsbrosjyre familievernet s. 4
} 
Familievernkontorene spiller den viktigste rollen blant meklerne. Regjeringen har uttalt at «familievernkontorene er grunnstammen i meklingsapparatet». ${ }^{65}$ Det er også innført et krav om at familievernet selv skal gjennomføre $75 \%$ av meklingssakene, og i 2013 foretok de 82,4 $\%$ av alle meklingene. ${ }^{66}$

Familievernet en spesialtjeneste innenfor familierelaterte problemer, og er hjemlet i lov om familievernkontorer av 19.06.1997 nr. 62 (heretter familievernkontorloven). Det finnes familievernkontorer i alle landets fylker, hvor de fleste er offentlige, mens noen er kirkelige. Alle kontorene er organisert under Bufetat. ${ }^{67}$ I tillegg til å foreta mekling, tilbyr familievernkontorene behandling og rådgivning til familier som har problemer, samt gir veiledning, informasjon og undervisning, jf. familievernkontorloven $\S 1$. Alle tilbud fra familievernkontoret er gratis. ${ }^{68}$ Familier eller enkeltpersoner kan selv henvende seg direkte til familievernkontorene, men de kan også henvises av institusjoner eller offentlig myndighet, jf. familievernkontorloven $\S 1(3)$.

\subsection{Barnets rett til å bli hørt}

Det følger av BK art. 12 og flere norske bestemmelser at barn har rett til å bli hørt i alle saker som angår dem. Rettigheten er dermed av både internasjonal og nasjonal karakter. I barneloven er retten hjemlet i $§ 31$, og ble lovfestet allerede ved barnelovens vedtakelse i $1981 .{ }^{69} \mathrm{I}$ internasjonal sammenheng var imidlertid BK art. 12 en nyskapning da konvensjonen ble vedtatt i 1989, og Norge var derfor tidlig ute på dette området. ${ }^{70}$ Etter inkorporeringen av barnekonvensjonen i norsk rett, ble barnets rett til å bli hørt ytterligere styrket i de nasjonale reglene for å være bedre i samsvar med konvensjonen. ${ }^{71}$ I 2014 ble retten også grunnlovsfestet i grl. § 104(1).

Barnets rett til bli hørt etter både $\mathrm{BK}$ art. 12 og bl. $\S 31$ gir barnet en rett til medbestemmelse, men ikke en rett til selvbestemmelse. Dette innebærer at barnet har rett til å uttale seg i saker som vedrører dem, og at det de sier blir tatt hensyn til. Barnet har imidlertid ingen rett til selv å treffe beslutninger i saken. Barnets rett til å bli hørt blir derfor ofte omtalt som en rett til

\footnotetext{
${ }^{65}$ St.meld.nr. 29 (2002-2003) s. 26

${ }^{66}$ Bufdir, Årsrapport (2013) s. 43, 45

${ }^{67}$ Bufetat, Presentasjonsbrosjyre familievernet s. 4

${ }^{68}$ Bufetat, Presentasjonsbrosjyre familievernet s. 2

${ }^{69}$ NOU 1977:35 s. 48, 123, Ot.prp.nr. 62 (1979-1980) s. 66

${ }^{70}$ Smith (2006) s. 34

${ }^{71}$ Smith (2006) s. 34
} 
deltakelse eller medvirkning. ${ }^{72}$ Barnet har videre ingen plikt til å uttale seg, og det er opp til barnet selv om det velger å benytte seg av retten eller ikke.

\subsubsection{Barnekonvensjonen art. 12}

Barnekonvensjonen art. 12 regnes som ett av konvensjonens fire generelle prinsipper. ${ }^{73}$ Dette innebærer at retten til å bli hørt både er en rettighet i seg selv, samtidig som den skal tas hensyn til ved anvendelsen av alle de andre bestemmelsene i konvensjonen.

Art. 12 nr. 1 inneholder en generell regel som fastslår at barn som er i stand til å danne seg egne synspunkter, skal gis retten til fritt å gi uttrykk for disse i alle forhold som vedrører barnet. Videre skal synspunktene tillegges behørig vekt, i samsvar med barnets alder og modenhet. Barnekomiteen har presisert at bestemmelsen favner vidt og skiller mellom to ulike former for deltakelse; barns rett til å bli hørt som gruppe og som enkeltpersoner. ${ }^{74}$ Førstnevnte knytter seg til barnets demokratiske deltakelse i samfunnet, og er av mer politisk karakter. Sistnevnte omhandler barnets deltakelse når det treffes individuelle avgjørelser, og er den mer rettslige formen. ${ }^{75}$ Den siste vil være fokus i det videre.

I art. 12 nr. 2 er barnets rett til å bli hørt i individuelle avgjørelser nærmere presisert. Bestemmelsen pålegger staten et særlig ansvar for å gi barnet anledning til å uttale seg i enhver rettslig og administrativ saksbehandling som angår barnet.

Art. 12 setter ingen aldersgrense for barnets uttalerett, men slår fast at retten gjelder for barn som er «i stand til å danne seg egne synspunkter». Barnekomiteen fraråder også statene å sette aldergrenser som vil begrense retten til å bli hørt. ${ }^{76}$ De har videre presisert at man bør legge til grunn at et barn er i stand til å danne seg egne synspunkter, og barnet skal selv ikke måtte bevise dette. ${ }^{77}$ Også barn som kan ha vanskelig for å uttrykke seg, slik som barn med funksjonsnedsettelser, minoritetsbarn, innvandrerbarn og andre som ikke kan språket, har rett til å bli hørt. ${ }^{78}$

\footnotetext{
${ }^{72}$ Sandberg (2012) s. 91

${ }^{73}$ General Comment No. 12 pkt. 2

${ }^{74}$ General Comment No. 12 pkt. 26-27, 9

${ }^{75}$ Sandberg (2012) s. 92-93

${ }^{76}$ General Comment No. 12 pkt. 21

${ }^{77}$ General Comment No. 12 pkt. 20

${ }^{78}$ General Comment No. 12 pkt. 21
} 
Dersom barnet velger å benytte seg av uttaleretten, skal meningen tillegges «behørig vekt» etter alder og modenhet. Det må derfor foretas en konkret vurdering i hver enkelt sak av hvor stor betydning barnets mening skal få. ${ }^{79}$

\subsubsection{Barneloven § 31}

Barneloven $\S 31$ hjemler barnets uttalerett i saker om personlige forhold for barnet. Dette omfatter i første rekke ulike typer spørsmål i forholdet mellom foreldre og barn. ${ }^{80}$

Bestemmelsens første ledd inneholder en generell, skjønnsmessig regel som er rettet mot foreldre og andre omsorgspersoner, for eksempel verger og fosterforeldre. ${ }^{81}$ Regelen pålegger disse en plikt til å høre barnets mening etter hvert som barnet blir i stand til å danne seg egne synspunkter, og en plikt til å vektlegge meningen etter barnets alder og modenhet.

I andre ledd er det slått fast at enhver som tar avgjфrelser om personlige forhold for barnet har plikt til å høre barnet, blant annet i saker om foreldreansvar, fast bosted og samvær. Dette gjelder ikke bare foreldre og omsorgspersoner, men også for eksempel når domstolene skal avgjøre en foreldretvist. Før slike avgjørelser tas, har barn som har fylt 7 år en absolutt uttalerett, mens yngre barn skal høres hvis de er i stand til å danne seg egne synspunkter. I 2014 ble det også lovfestet at barnet har krav på å få informasjon, da dette er en forutsetning for å kunne uttrykke sine synspunkter. ${ }^{82}$ Dersom barnet velger å uttale seg, skal meningen vektlegges etter alder og modenhet, i tråd med BK art. 12. Når barnet er fylt 12 år, skal imidlertid meningen tillegges stor vekt.

Grensen for barnets absolutte uttalerett ble i 2004 senket fra 12 år til 7 år, i forbindelse med inkorporeringen av barnekonvensjonen i norsk rett. ${ }^{83}$ Som nevnt setter BK art. 12 ingen aldersgrense for uttaleretten, og barnekomiteen fraråder også statene å gjøre dette. Lovgiver mente imidlertid at en ubetinget uttalerett fra 7 år ville være et effektivt virkemiddel for å sikre at barn ned til denne alderen blir hørt, og at det i praksis ville føre til at flere barn enn tidligere ville komme til ordet. ${ }^{84}$ Det er lagt til grunn at en slik aldersgrense ikke er i strid med BK art. 12, så lenge den suppleres med en skjønnsmessig regel for dem som er yngre, slik som bl. $\S 31$ gjør. $^{85}$

\footnotetext{
${ }^{79}$ General Comment No. 12 pkt. 28-31

${ }^{80}$ Ot.prp.nr. 29 (2002-2003) s. 60

${ }^{81}$ Ot.prp.nr. 29 (2002-2003) s. 57

${ }^{82}$ Prop.85 L (2012-2013) s. 38, 86

${ }^{83}$ Ot.prp.nr. 29 (2002-2003) s. 60

${ }^{84}$ Ot.prp.nr. 29 (2002-2003) s. 61

${ }^{85}$ Sandberg (2012) s. 100
} 


\section{Barnets rett til å bli hørt i meklingen de lege lata}

Barnets rett til å bli hørt i forbindelse med den obligatoriske meklingen har vært under debatt $\mathrm{i}$ norsk sammenheng. Flere fagpersoner har hevdet at meklingsordningen ikke i tilstrekkelig grad ivaretar barnets rett til å bli hørt etter BK art. 12. ${ }^{86} \mathrm{Jeg}$ vil derfor i det følgende foreta en rettsdogmatisk analyse av de relevante nasjonale reglene og BK art. 12, for å vurdere om de er i samsvar.

\subsection{Nasjonale regler}

Meklingen har til formål å hjelpe foreldrene med å komme fram til en avtale om foreldreansvar, fast bosted og samvær. Det er ingen tvil om at dette er «personlige forhold» for barnet, og at barnet derfor har rett til å bli hørt etter bl. § 31. I forbindelse med meklingen er det imidlertid foreldrene selv som skal treffe avgjørelsen, og ikke mekler. Mekler har derfor ingen plikt til å høre barnet etter bl. § 31(2), og det er følgelig foreldrenes ansvar etter bl. § 31 .

Det samme er lagt til grunn i meklingsforskriften. Her fremgår det at mekler skal «gjøre foreldrene oppmerksomme» på barnets rett til å bli hørt, jf. § 2. Ifølge departementet presiserer denne bestemmelsen at det er foreldrene som har ansvaret for å høre barnet i forbindelse med meklingen, mens mekler kun har plikt til å informere foreldrene om dette. ${ }^{87}$

I de nasjonale reglene finnes det derfor ingen hjemmel som gir mekler hverken rett eller plikt til å høre barnet. Mekler er heller ikke pålagt noe ansvar for å påse at foreldrene faktisk hører barnet.

Når barnekonvensjonen er gjort til norsk lov, blir imidlertid alle myndigheter, organisasjoner og enkeltpersoner direkte forpliktet av konvensjonens bestemmelser. ${ }^{88}$ Også mekler har derfor et ansvar for å ivareta barnets rett til å bli hørt etter BK art. 12. Det samme er lagt til grunn i forarbeider til endringer i barneloven, hvor det fremgår at mekler etter utvalgets oppfatning har et «særskilt ansvar» for å påse at barn høres. ${ }^{89}$

Både $\mathrm{i}$ forarbeidene og $\mathrm{i}$ en stortingsmelding er det videre uttalt at det er opp til den enkelte mekler å avgjøre om barna skal trekkes inn i meklingen, men det påpekes samtidig at dette skjer i liten grad. ${ }^{90}$ Av forarbeidene fremgår det videre at:

\footnotetext{
${ }^{86}$ Bla. Sandberg (2010) s. 59-60, Haugen (2010) s. 126, Barneombudet (2012) s. 32

${ }^{87}$ Rundskriv Q-02/2008 s. 6

${ }^{88}$ Smith (2012) s. 20

${ }^{89}$ NOU 1998:17 s. 45

${ }^{90}$ NOU 1998:17 s. 44, St.meld.nr. 29 (2002-2003) s. 26
} 
«Hvordan barnet høres kan det ikke oppstilles generelle retningslinjer for. Hvorvidt mekler skal samtale med barnet, eller om han skal la foreldrene gjøre det, må avgjøres i samarbeid mellom mekler og foreldre». ${ }^{91}$

Det er dermed åpnet for muligheten at mekler kan snakke med barnet selv. Mangelen på lovregler for dette, medfører imidlertid at begge foreldrene må samtykke for at mekler skal kunne høre barnet. Det følger av foreldreansvaret, som gir foreldrene rett og plikt til å ta avgjørelser for barnet, jf. bl. § 30 .

Etter de nasjonale reglene vil det derfor fullt og helt bero på foreldrene om barnets rett til å bli hørt blir ivaretatt i forbindelse med meklingen eller ikke.

\subsection{Statens særlige ansvar etter BK art. $12 \mathrm{nr} .2$}

Det har tidligere vært diskutert i norsk sammenheng om mekling er omfattet av BK art. $12 \mathrm{nr}$. 2, som pålegger staten et særlig ansvar for å ivareta barnets rett til å bli hørt i «rettslig og administrativ saksbehandling». ${ }^{92}$

Saksbehandling i tradisjonell forstand krever at det treffes en avgjørelse av forvaltningen eller retten, slik som når dommeren avgjør en foreldretvist. Dette er ikke tilfelle ved meklingen, ettersom det er foreldrene selv som skal komme fram til en avtale. I vid forstand kan imidlertid begrepet saksbehandling brukes om all virksomhet som drives av det offentlige, uten at det treffes noen avgjørelse. Siden meklingen er en obligatorisk ordning som det offentlige er ansvarlige for, kan meklingen sies å være saksbehandling i vid forstand. ${ }^{93}$

I generell kommentar nr. 12 har barnekomiteen nå fastslått at alternative tvisteløsningsmetoder, som mekling og voldgift, omfattes av begrepet «saksbehandling». ${ }^{94}$ Mekling ved samlivsbrudd er også uttrykkelig nevnt. ${ }^{95}$ I teorien er det lagt til grunn at dette løser spørsmålet. ${ }^{96}$ Staten har derfor et særlig ansvar etter BK art. 12 nr. 2 for å ivareta barnets rett til å bli hørt i forbindelse med meklingen.

På denne bakgrunn vil jeg i det følgende se på hvilke krav som stilles etter BK art. 12 nr. 2. Jeg vil ta for meg fire problemstillinger som er omdiskutert: om det er tilstrekkelig at foreld-

\footnotetext{
${ }^{91}$ NOU 1998:17 s. 45

${ }^{92}$ Sandberg (2010) s. 55, Sandberg (2012) s. 103

${ }^{93}$ Sandberg (2012) s. 103 fotnote 214

${ }^{94}$ General Comment No. 12 pkt. 32

${ }^{95}$ General Comment No. 12 pkt. 50-52

${ }^{96}$ Sandberg (2012) s. 103
} 
rene hører barnets mening (4.3), hvordan barnet skal høres (4.4), om barnets rett til å bli hørt er absolutt (4.5) og om det er i strid med BK at foreldrene kan nekte barnet å delta i meklingen (4.6).

\subsection{Er det tilstrekkelig at foreldrene hører barnets mening?}

\subsubsection{Direkte, ved representant eller egnet organ}

BK art. 12 nr. 2 oppstiller tre muligheter for hvem som kan høre barnet i rettslig og administrativ saksbehandling. Barnet kan enten høres «direkte», ved en «representant» eller gjennom et «egnet organ».

Konvensjonen legger selv ingen føringer på hvilket av alternativene som er å foretrekke eller hvem som skal ta valget mellom disse. Dette tilsier at det er opp til staten å bestemme. ${ }^{97}$ Imidlertid har barnekomiteen uttalt at det er barnet selv som skal ta valget, og at barnet før høringen må få informasjon om valget mellom å høres direkte eller gjennom en representant. ${ }^{98} \mathrm{I}$ teorien er det lagt til grunn at dette neppe kan kreves av statene, selv om det er i tråd med barneperspektivet i konvensjonen. ${ }^{99}$ Det er dermed noe uklart hvem som skal ta valget.

Uansett anbefaler barnekomiteen at barnet gis anledning til å bli hørt «direkte» i enhver saksbehandling der dette er mulig. ${ }^{100}$ At barnet høres «direkte» vil si at det høres under saksbehandlingen, av en som sitter i det organet som behandler saken. ${ }^{101}$ I dette tilfellet vil det være mekleren. Ettersom det offentlige har ansvaret for både meklingsordningen og for opplæring og godkjenning av meklere, er det fullt mulig å legge til rette for at barnet høres direkte av mekleren. Likevel er dette ikke et krav fra barnekomiteens side, men en anbefaling, slik at staten må ha et visst rom for skjønn i forhold til hvem som hører barnet. ${ }^{102}$

Når de nasjonale reglene ikke legger opp til at mekler skal høre barnet, blir det mest relevant å vurdere om foreldrene kan brukes som barnets «representant» etter BK art. 12 nr. 2.

\subsubsection{Foreldrene som barnets representant?}

BK art. 12 nr. 2 sier ingenting om hvem som kan være «representant» for barnet eller hvem som skal velge denne. Også her må det derfor være opp til staten å avgjøre. ${ }^{103}$

\footnotetext{
${ }^{97}$ Sandberg (2012) s. 107

${ }^{98}$ General Comment No. 12 pkt. 35, 41

${ }^{99}$ Sandberg (2012) s. 107, Søvig (2009) s. 69

${ }^{100}$ General Comment No. 12 pkt. 35

${ }^{101}$ Sandberg (2012) s. 107

102 Søvig (2009) s. 69-70

${ }^{103}$ Sandberg (2012) s. 107-108
} 
Barnekomiteen nevner foreldre, advokat og sosialarbeider som eksempler, og omtaler videre foreldrene som barnets mest nærliggende representant. ${ }^{104}$ I saker som angår forholdet mellom barn og foreldre, slik som spørsmålene om foreldreansvar, fast bosted og samvær gjør, er det naturlig at foreldrene selv snakker med barnet. Dette gjelder særlig når foreldrene skal ta avgjørelsen selv, noe som også er lagt til grunn i norsk rett. I forbindelse med meklingen som dommeren kan foreta under saksforberedelsen etter bl. $\S 61$, har lovgiver uttalt at «særlig i tilfeller der det mekles mellom foreldrene under saksforberedelsen etter lovutkastet $\S 61$, antar departementet at det $\mathrm{i}$ en del saker vil være slik at foreldrenes opplysninger om barnets syn kan legges til grunn, forutsatt at de er enige om hva barnet mener og ikke andre forhold tilsier at barnet likevel bør høres». ${ }^{105}$ Det samme er gjentatt i departementets veileder om høring av barn i saker for domstolene. ${ }^{106}$ Dette taler for at det er tilstrekkelig å bruke foreldrene som representant også i forbindelse med meklinger på familievernkontoret.

På den annen side påpeker barnekomiteen at det i mange saker vil være en risiko for interessekonflikt mellom barnet og foreldrene. ${ }^{107}$ Det er presisert at dersom barnet skal høres gjennom en representant, er det høyst viktig at barnets mening formidles korrekt av representanten. ${ }^{108}$ Representanten må også være klar over at den utelukkende representerer barnets interesser, og ikke interessene til andre personer, for eksempel foreldrene. ${ }^{109}$

Saker om fast bosted og samvær etter samlivsbrudd er typiske tilfeller hvor det kan være fare for interessekonflikt, fordi foreldrene selv er så personlig involvert i saken. ${ }^{110}$ I veilederen om høring av barn i foreldretvister, har departementet lagt til grunn at når uenigheten mellom foreldrene er så stor at de ikke er enige om barnets mening, bør dommer eller sakkyndig høre barnet. ${ }^{111}$ Det er svært sannsynlig at heller ikke alle foreldrene som møter til mekling på familievernkontoret er enige om barnets mening, ettersom mange ikke har klart å komme fram til en avtale om barnet. Dette taler for at foreldre som er uenige heller ikke er egnet som representant i forbindelse med meklingen.

\footnotetext{
104 General Comment No. 12 pkt. 36

105 Ot.prp.nr. 29 (2002-2003) s. 62

106 Veileder Q-15/2004 s. 39

107 General Comment No. 12 pkt. 36

108 General Comment No. 12 pkt. 36

${ }^{109}$ General Comment No. 12 pkt. 37

${ }^{110}$ Sandberg (2012) s. 108

111 Veileder Q-15/2004 s.40
} 
Sandberg påpeker imidlertid at det kan være fare for interessekonflikt også der foreldrene er enige om barnets synspunkter. ${ }^{112}$ Dette fordi foreldrene selv er så involvert i konflikten at de kan ha vanskelig for å «se» barnet fullt ut og klare å skille mellom sine egne og barnets ønsker. ${ }^{113}$ Det er dermed fare for at foreldrene ikke klarer å oppfatte hva barnet mener eller formidle barnets syn på en nøytral måte. ${ }^{114}$ Dette kan tilsi at foreldrene ikke i noen tilfeller er egnet som representant for barnet i forbindelse med meklingen.

Barnekomiteen har også uttalt at representanten må ha tilstrekkelig kunnskap og forståelse av de ulike aspektene ved beslutningsprosessen, og erfaring i å jobbe med barn. ${ }^{115}$ Det er tvilsomt om foreldrene vil oppfylle disse kravene, særlig sett i lys av deres egen involvering $\mathrm{i}$ konflikten.

Til tross for at foreldrene er barnets mest nærliggende representant, er det dermed fare for at de ikke klarer å formidle barnets mening korrekt, at de ikke utelukkende klarer å representere barnets interesser og at de ikke har tilstrekkelig kunnskap. Dette tilsier at de ikke er egnet som representant for barnet i meklingen.

\subsubsection{Retten til informasjon}

Det kan også stilles spørsmål ved om barnet vil få nødvendig og tilstrekkelig informasjon til å kunne uttale seg dersom foreldrene er barnets representant.

BK art. 12 inneholder ingen uttrykkelig rett til informasjon for barnet, men det er presisert både av barnekomiteen og i norsk rett at dette er en forutsetning for at barnet skal kunne uttale seg. ${ }^{116}$ Som nevnt i pkt. 3.3.2, er retten til informasjon nå lovfestet i bl. § 31(2). Ifølge både barnekomiteen og departementet er det den som skal høre barnet som er ansvarlig for å gi barnet informasjon. ${ }^{117}$

I en stortingsmelding har regjeringen presisert at det i utgangspunktet er foreldrenes plikt og rett å gi barna nødvendig informasjon i forbindelse med meklinger på familievernkontoret. ${ }^{118}$ Samtidig påpeker de følgende:

\footnotetext{
${ }^{112}$ Sandberg (2012) s. 108

${ }^{113}$ Sandberg (2010) s. 59-60, Sandberg (2012) s. 108

${ }^{114}$ Sandberg (2012) s. 108

115 General Comment No. 12 pkt. 36

${ }^{116}$ General Comment No. 12, pkt. 25, Veileder Q-15/2004 s. 40

117 General Comment No. 12, pkt. 25, 41, Veileder Q-15/2004 s. 40

118 St.meld.nr. 29 (2002-2003) s. 28
} 
«I tilfeller der foreldrene er i sterk og vedvarende konflikt med hverandre kan den informasjonen barnet får bli preget av dette. Det kan i slike tilfeller være en god løsning at foreldrene tar med seg barna til mekling. Mekler kan hjelpe dem med å gi barnet nødvendig informasjon tilpasset barnets behov, og legge til rette for at barnet kan få uttale seg dersom det ønsker det. Det må være opp til mekler å vurdere hvorvidt det er en god løsning å bringe barnet inn i meklingen». ${ }^{119}$

Denne uttalelsen indikerer at foreldrene heller ikke alltid vil klare å gi barna nødvendig og tilstrekkelig informasjon til å kunne uttale seg, og støtter at det i enkelte tilfeller kan være behov for at andre enn foreldrene snakker med barnet.

Samlet er det derfor mange argumenter som tilsier at foreldrene ikke er egnet som barnets representant i meklingen. Samtidig er det fullt mulig å legge til rette for at mekler hører barnet direkte, slik barnekomiteen anbefaler. Selv om barnekomiteens uttalelser ikke er rettslig bindende, tyder mye på at barnets rett til å bli hørt vil bli best ivaretatt dersom mekler hører barnet.

\subsection{Hvordan skal barnet høres?}

Neste spørsmål som reiser seg, er hvordan barnet skal høres i rettslig og administrativ saksbehandling.

Det følger av BK art. 12 nr. 2 at høringen skal skje på en måte som er «i samsvar med saksbehandlingsreglene i nasjonal rett». Barnekonvensjonen legger dermed ingen klare føringer på gjennomføringsmåten, noe som tilsier at det er opp til den enkelte stat å avgjøre. Barnekomiteen har imidlertid presisert at dette ikke åpner for at statene kan begrense retten til å bli hørt. ${ }^{120}$ Tvert imot er det ment å understreke behovet for at det i nasjonal rett finnes spesifikke regler for hvordan retten skal ivaretas. ${ }^{121}$

I norsk rett finnes det ingen klare regler for hvordan høringen skal gjennomføres. Det vil derfor være opp til den som skal snakke med barnet å avgjøre. ${ }^{122}$ Departementet har imidlertid utarbeidet veiledere og brosjyrer som kan være til hjelp. Blant disse er eksempelvis brosjyren «Barn og samlivsbrudd» som gir råd og veiledning til foreldrene, ${ }^{123}$ og den tidligere nevnte veilederen om høring av barn i foreldretvister. ${ }^{124}$

\footnotetext{
${ }^{119}$ St.meld.nr. 29 (2002-2003) s. 28

${ }^{120}$ General Comment No. 12 pkt. 38

${ }^{121}$ Manual on Human Rights Reporting (1997) s. 430

${ }^{122}$ Sandberg (2012) s. 110

${ }^{123}$ Brosjyre Q-1069

${ }^{124}$ Veileder Q-15/2004
} 
Selv om BK art. 12 nr. 2 ikke sier hvordan høringen skal foregå, følger det av BK art. 12 nr. 1 at barnet skal kunne uttrykke seg «fritt». Dette vil legge visse føringer på gjennomføringsmåten. I tillegg har barnekomiteen kommet med anbefalinger. Jeg vil i det følgende gjennomgå disse.

\subsubsection{Uttrykke seg «fritt»}

BK art. 12 nr. 1 stiller krav om at barnet skal få uttrykke sine synspunkter «fritt». Ifølge barnekomiteen ligger det mye i dette begrepet. ${ }^{125}$ Barnet skal kunne uttrykke sine synspunkter uten press, og selv velge om det vil benytte seg av retten til å bli hørt. Barnet skal ikke manipuleres eller utsettes for utilbørlig påvirkning eller press. Videre har barnet rett til å gi uttrykk for sine egne synspunkter og ikke andres.

Et spørsmål som reiser seg hvis mekler skal høre barnet, er om barnet kan uttrykke seg «fritt» med foreldrene til stede under høringen.

Hverken barnekonvensjonen eller barnekomiteen sier noe direkte om dette spørsmålet. Barnekomiteen legger imidlertid stor vekt på at man må ta hensyn til barnets individuelle og sosiale situasjon, slik at alle barn kan føle seg frie til å uttrykke sine synspunkter. ${ }^{126}$ Dette tilsier at det ikke kan oppstilles klare regler for hvorvidt foreldrene skal være til stede.

I norsk sammenheng har departementet uttalt på generelt grunnlag at det for de fleste barn før tenårene er best dersom minst en av foreldrene er med på samtaler med ukjente. ${ }^{127}$ Samtidig påpeker de at dette kan stille seg noe annerledes i saker der foreldrene er uenige om foreldreansvar, fast bosted eller samvær, fordi foreldrene da direkte eller indirekte vil kunne påvirke samtalen på en uheldig måte. I slike saker vil mange barn snakke mer fritt uten foreldrene til stede, fordi de da ikke trenger å være redd for å si noe galt eller for å såre en av foreldrene. ${ }^{128}$ Ifølge departementet må belastningen ved å snakke med en fremmed alene, derfor avveies mot belastningen det kan være å ha foreldrene til stede. ${ }^{129}$ Dette synes å være i tråd med barnekomiteens anbefalinger om å tilpasse situasjonen til det enkelte barn.

Sandberg mener imidlertid at kravet om å uttrykke seg «fritt» innebærer at det må utarbeides ordninger som gjør at barnet kan føle seg trygg i samtalesituasjonen uten noen av foreldrene

\footnotetext{
${ }^{125}$ General Comment No. 12 pkt. 22

${ }^{126}$ General Comment No. 12 pkt. 23

${ }^{127}$ Veileder Q-15/2004 s. 46

${ }^{128}$ Veileder Q-15/2004 s. 46

${ }^{129}$ Veileder Q-15/2004 s. 46
} 
til stede. ${ }^{130}$ Hun legger vekt på at i saker om fast bosted og samvær vil mange barn føle press fra minst en av foreldrene til å komme med et bestemt syn. ${ }^{131}$

Det er derfor ingen klar konklusjon på hvorvidt foreldrene kan være til stede under høringen eller ikke. Mye tyder på at dette må avgjøres ut fra det enkelte barns situasjon. I alle tilfeller er det imidlertid viktig at den som snakker med barnet er oppmerksom på faren for at barnet føler press fra foreldrene, og prøver å finne ut om dette er tilfelle. ${ }^{132}$

\subsubsection{Barnevennlige forhold}

Barnekomiteen legger stor vekt på at alle forhold rundt høringen av barnet må være barnevennlige. Dette gjelder både informasjonen barnet gis, selve høringen, og de fysiske omgivelsene. ${ }^{133}$

Som nevnt i pkt. 4.3.2.1 er det en grunnleggende forutsetning at barnet i forkant av høringen får nødvendig og tilstrekkelig informasjon. Barnet må blant annet informeres om saken, retten til å uttale seg, betydningen det har at barnet uttrykker sine synspunkter, mulige konsekvenser av barnets valg, hvordan og når høringen vil bli gjennomført, og at barnet når som helst kan trekke seg fra høringen. ${ }^{134}$ Hvis barnet velger å uttale seg, skal barnet også informeres om utfallet av prosessen, og hvordan synspunktene er blitt tatt hensyn til. ${ }^{135}$ I 2014 ble det lovfestet i barneloven $\S 61 \mathrm{nr} .4$ at når domstolen avgjør en foreldretvist, skal dommer eller sakkyndig gi barnet slik tilbakemelding. Dette for å være bedre i samsvar med barnekomiteens anbefalinger. ${ }^{136}$

Informasjonen som gis barnet må være tilpasset barnets alder og modenhet. ${ }^{137}$ Den må derfor fremstilles på en måte barnet forstår og forenkles i den grad det er nødvendig, samtidig som den ikke skal gi et skjevt bilde av saken. ${ }^{138}$ Barnekomiteen har påpekt at det er særlig viktig med utarbeiding og utdeling av barnevennlig informasjon i forbindelse med rettslig og administrativ saksbehandling. ${ }^{139}$

\footnotetext{
${ }^{130}$ Sandberg (2012) s. 111

${ }^{131}$ Sandberg (2012) s. 110

${ }^{132}$ Sandberg (2012) s. 110

${ }^{133}$ General Comment No. 12 pkt. 34

${ }^{134}$ General Comment No. 12 pkt. 25, 41, 134(a), 134(b)

135 General Comment No. 12 pkt. 45

${ }^{136}$ Prop.85 L (2012-2013) s. 40

${ }^{137}$ General Comment No. 12 pkt. 134(a), Veileder Q-15/2004 s. 40, 41

138 Sandberg (2012) s. 113

${ }^{139}$ General Comment No. 12 pkt. 34
} 
At selve høringen skal være barnevennlig, innebærer at barnet må kunne føle seg respektert og trygg under samtalen. ${ }^{140}$ Omgivelsene må være positive og oppmuntrende, slik at barnet føler seg sikker på at den ansvarlige for høringen er villig til å lytte og ta barnets synspunkter på alvor. ${ }^{141}$ Barnekomiteen anbefaler at høringen foretas i form av en samtale, heller enn en enveis utspørring. ${ }^{142}$ For at høringen skal være effektiv og meningsfull, er det påpekt at høringen må bli forstått som en prosess, og ikke som en individuell engangshendelse. ${ }^{143}$ I enkelte tilfeller, særlig dersom saken gjelder hendelser som har vært til skade for barnet, må imidlertid ikke barnet høres oftere enn nødvendig, da høringen kan være en vanskelig prosess som kan ha traumatisk virkning på barnet. ${ }^{144}$ Det er da viktig at samtalen gjennomføres på en så skånsom måte som mulig. ${ }^{145}$

Også de fysiske omgivelsene rundt høringen må være tilpasset barnets alder, slik at de ikke fremstår som truende, fiendtlige eller ufølsomme. Dette innebærer blant annet at lokaler og antrekk må tilrettelegges, og høringen bør foretas under fortrolige forhold. ${ }^{146}$

\subsubsection{Tilpasset det enkelte barn}

Barnekomiteen fremhever at gjennomføringen også må tilpasses det enkelte barn. Metoden og forholdene rundt høringen må ta hensyn til barnets individuelle og sosiale situasjon, og tilpasses barnets kapasitet og evner. Det må tas hensyn til at barn i varierende grad har behov for støtte og tilrettelegging, alt etter deres alder og utvikling, og det skal være tilstrekkelig tid og ressurser tilgjengelig for å kunne tilpasse forholdene til hvert enkelt barn. ${ }^{147}$

Det er også viktig å legge til rette for at små barn og andre barn som har problemer med å få uttrykt sine synspunkter skal få mulighet til å bli hørt. ${ }^{148}$ I forhold til små barn krever dette at man anerkjenner og respekterer ikke-verbale former for kommunikasjon, som lek, kroppsspråk, ansiktsuttrykk, tegning og maling. Barn med nedsatt funksjonsevne bør utstyres med, og gjøres i stand til å bruke, de kommunikasjonshjelpemidler de trenger for å kunne uttrykke seg. Det må også legges til rette for at barn som tilhører minoriteter og urbefolkninger, samt innvandrerbarn får si sin mening.

\footnotetext{
${ }^{140}$ General Comment No. 12 pkt. 23

${ }^{141}$ General Comment No. 12 pkt. 42

${ }^{142}$ General Comment No. 12 pkt. 43

${ }^{143}$ General Comment No. 12 pkt. 133

${ }^{144}$ General Comment No. 12 pkt. 24

${ }^{145}$ General Comment No. 12 pkt. 21, Sandberg (2010) s. 66

${ }^{146}$ General Comment No. 12 pkt. 34, 43

${ }^{147}$ General Comment No. 12 pkt. 23, 36, 134(e)

${ }^{148}$ General Comment No. 12 pkt. 21
} 


\subsubsection{Krav til kompetanse}

Dersom man skal kunne gjennomføre høringen i tråd med barnekomiteens anbefalinger, vil det kreve særskilt kompetanse hos den som skal snakke med barnet.

Barnekomiteen fremhever at de voksne må være godt forberedt og ha de ferdigheter og hjelpemidler som trengs. ${ }^{149}$ Det innebærer at de må være godt kvalifisert når det gjelder å lytte til barn, samarbeide med dem og engasjere dem på en effektiv måte, i samsvar med deres gradvise utvikling. For å sikre dette, må staten sørge for opplæring i BK art. 12 og dens anvendelse i praksis for alle fagpersoner som arbeider for og med barn, herunder offentlig ansatte. ${ }^{150}$ Barnekomiteen anbefaler videre at det utarbeides programmer for foreldreopplæring, og at det spres informasjon om barns og foreldres rettigheter etter konvensjonen. ${ }^{151}$

Det er liten tvil om at staten vil å ha bedre mulighet til å sikre meklere den nødvendige kompetansen enn foreldrene. Også dette kan tilsi at retten til å bli hørt vil bli bedre oppfylt dersom mekler hører barnet.

\subsection{Er barnets rett til å bli hørt absolutt?}

Som gjennomgått i pkt. 3.1.1, følger det av både BK art. 3 og bl. § 48 at «barnets beste» skal være et grunnleggende hensyn i alle forhold som vedrører barn. Et spørsmål som reiser seg i denne sammenheng, er om barnets uttalerett kan settes til side fordi man mener det ikke er til «barnets beste» å bli hørt.

I norsk rett har lovgiver lagt til grunn at barn som har fylt 7 år har en absolutt uttalerett. Dersom retten ikke ivaretas, er dette en saksbehandlingsfeil som kan føre til opphevelse av den rettslige avgjørelsen, jf. blant annet Rt. 1999 s. 1183 og Rt. 2006 s. $929 .{ }^{152}$

Spørsmålet har imidlertid blitt satt på spissen av Høyesterett i Rt. 2004 s. 811. Saken gjaldt endring av dom om samvær, jf. nå bl. § 64(2). I forbindelse med den nye saken var en gutt født i 1991 ikke spurt om å uttale seg, og spørsmålet var om dette var en saksbehandlingsfeil. Etter en konkret vurdering kom Høyesterett enstemmig til at det ikke var en saksbehandlingsfeil.

I dommen uttaler Høyesterett at utgangspunktet var at barnet skulle høres, men at dette synspunktet ikke står like sterkt når det er snakk om endring av samværsordningen, som det ville

\footnotetext{
${ }^{149}$ General Comment No. 12 pkt. 134(g)

${ }^{150}$ General Comment No. 12 pkt. 49

${ }^{151}$ General Comment No. 12 pkt. 93

${ }^{152}$ Bla. Prop. 85 L (2012-2013) s. 35
} 
ha stått ved den opprinnelige prøvingen. ${ }^{153}$ Videre sier Høyesterett at barnets uttalerett «i alle tilfelle» må vurderes i lys av barnets personlige forutsetninger, og at «barnets beste» må være styrende for denne vurderingen. ${ }^{154}$ Disse uttalelsene tyder på at Høyesterett mener barnets rett til å bli hørt ikke er absolutt, og at retten kan måtte vike for hensynet til «barnets beste».

I den konkrete vurderingen kom Høyesterett til at det ikke var til barnets beste å uttale seg. For at en tidligere dom om samvær skal kunne endres, må det foreligge «særlige grunner», jf. nå bl. § 64(2). Dersom det er åpenbart at slike grunner ikke foreligger, kan retten avgjøre saken uten hovedforhandling, jf. nå bl. 64(3). Retten mente i dette tilfellet at det ikke var grunnlag for en realitetsvurdering, og at det derfor heller ikke var nødvendig å snakke med gutten. Det ble også lagt vekt på at det forelå en sterk konfliktsituasjon mellom foreldrene, hvor barna var trukket sterkt inn. Gutten hadde særlige problemer, og det var derfor behov for å verne ham. $^{155}$

I juridisk teori har flere kritisert dommen, ikke for sitt resultat, men for de generelle uttalelsene i begrunnelsen. Blant annet hevder Smith, Sandberg og Holgersen at det er i strid med BK art. 12 at barnets uttalerett alltid skal vurderes i lys av barnets beste, og at uttalelsene må sees i sammenheng med de spesielle forholdene i saken. ${ }^{156}$ Ifølge Sandberg må uttalelsene tolkes slik at de sier noe om «unntakstilfellene der høring åpenbart kan være skadelig for barnet». ${ }^{157}$ Smith presiserer videre at barnets beste først skal komme inn i vurderingen av hvor stor vekt meningen skal tillegges. ${ }^{158}$

Kjølberg/Johansen og Søvig støtter derimot at retten til å bli hørt undertiden kan måtte vike for hensynet til barnets beste. ${ }^{159}$ Søvig presiserer imidlertid at terskelen for å ekskludere barn fra uttaleretten må være høy, siden denne rettigheten er en av grunnpilarene i barnekonvensjonen. ${ }^{160}$

Barnekonvensjonen selv prioriterer ikke mellom barnets beste og barnets rett til å bli hørt. Barnekomiteen har uttrykt at det ikke foreligger noen spenning mellom art. 3 og art. 12, men tvert imot at de utfyller hverandre ved at barnets beste ikke kan bli korrekt oppfylt dersom

\footnotetext{
${ }^{153}$ Rt-2004-811 avsn. 47

${ }^{154}$ Rt-2004-811 avsn. 37, 47

${ }^{155}$ Rt-2004-811 avsn. 49

${ }^{156}$ Smith (2004) s. 229-231, Sandberg (2012) s. 103, Holgersen (2008) s. 295-296

${ }^{157}$ Sandberg (2012) s. 103

${ }^{158}$ Smith (2004) s. 229-230

${ }^{159}$ Kjølberg (2006) s. 201-202, Søvig (2009) s. 81

${ }^{160}$ Søvig (2009) s. 81
} 
barnets rett til å bli hørt ikke er respektert. ${ }^{161}$ Ifølge barnekomiteen er oppfyllelsen av art. 12 derfor et obligatorisk trinn i handlingsprosessen med å ivareta barnets beste. ${ }^{162}$ Dette tilsier at barnekomiteen mener barnets rett til å bli hørt aldri kan fravikes, heller ikke ut fra en vurdering av barnets beste. Dette samsvarer med formålet med BK art. 12, som er å gi barnet en selvstendig rett. ${ }^{163}$ Det skal ikke være opp til de voksne å bestemme om barnet skal få uttale seg eller ikke. ${ }^{164}$ Barnet skal selv kunne ta dette valget, og det er da en forutsetning at barnet blir spurt om det vil benytte seg av retten eller ikke.

Dette tilsier at barnets rett til å bli hørt som hovedregel ikke kan settes til side ut fra hensynet til barnets beste. Ut i fra synspunktene i teorien, vil det eventuelt kun være i helt spesielle tilfeller at dette vil være mulig, slik som i dommen.

\subsection{Er det i strid med BK at foreldrene kan nekte barnet å delta i meklingen?}

Som gjennomgått i pkt. 4.3, er det ikke en direkte plikt etter BK at barnet høres av mekleren, men mye tyder på at dette bedre vil ivareta barnets uttalerett. I de nasjonale reglene er det imidlertid foreldrenes ansvar å høre barnet, og mekler har ingen rett til å snakke med barnet med mindre begge foreldrene samtykker. Samtidig tyder drøftelsen over på at uttaleretten som hovedregel er absolutt. Det kan derfor stilles spørsmål ved om det er i strid med barnekonvensjonen at foreldrene kan nekte barnet å delta i meklingen.

\subsubsection{Begrepet «rett» og formålet med art. 12}

BK art. 12 gir barnet en «rett» til å gi uttrykk for sine synspunkter og en rett til at disse blir tillagt behørig vekt. Dette innebærer at barnet ikke har plikt til å uttrykke seg, men skal ha mulighet dersom det $\varnothing$ nsker det. ${ }^{165}$ Formålet med art. 12 er å gi barnet rettigheter som gir det innflytelse over sitt eget liv, og ikke bare rettigheter på grunn av sin sårbarhet (retten til beskyttelse), eller sin avhengighet til voksne (retten til omsorg). Barnekonvensjonen som helhet anerkjenner barnet som innehaver av rettigheter, og dermed som eget rettssubjekt. ${ }^{166}$ Dersom foreldrene skal kunne avgjøre om barnet skal få uttale seg, vil det ikke bli en selvstendig rett for barnet. Både ordlyden og formålet med art. 12 tilsier derfor at barnets uttalerett ikke kan være avhengig av foreldrenes samtykke.

\footnotetext{
${ }^{161}$ General Comment No. 12 pkt. 74

162 General Comment No. 12 pkt. 70

163 General Comment No. 12 pkt. 18

${ }^{164}$ Sandberg (2012) s. 103

165 General Comment No. 12 pkt. 15, 16

${ }^{166}$ General Comment No. 12 pkt. 18
} 


\subsubsection{Statens forpliktelser}

I forlengelsen av dette, er det relevant å vurdere om staten har oppfylt sine forpliktelser etter barnekonvensjonen når barnets uttalerett i meklingen er gjort avhengig av foreldrenes samtykke.

BK art. 4 pålegger staten å treffe «alle egnede lovgivningsmessige, administrative og andre tiltak» for å gjennomføre konvensjonens rettigheter. Dette innebærer at staten har en plikt til å forankre retten til å bli hørt i lovgivningen, slik at den respekteres av alle myndigheter, organisasjoner, institusjoner og enkeltpersoner som treffer avgjørelser for barna, og pålegge foreldrene plikter. ${ }^{167}$ Videre må det iverksettes tiltak for en effektiv gjennomføring i praksis. ${ }^{168}$

I BK art. $12 \mathrm{nr} .1$ er det presisert at staten «skal garantere» barnets rett til å bli hørt. Ifølge barnekomiteen er dette et juridisk uttrykk med spesiell styrke, som ikke etterlater staten noe rom for skjønn. Staten har derfor ingen frihet til å vurdere hvorvidt barn skal gis rett til å bli hørt eller ikke, men er strengt forpliktet til å treffe egnede tiltak for å gjennomføre retten fullt ut for alle barn. ${ }^{169}$ Også uttrykket «bli hørt» viser at noen har ansvar for å sørge for at retten blir ivaretatt. ${ }^{170}$ Barnekomiteen har videre understreket at gjennomføringen av de generelle prinsippene, inkludert art. 12, ikke kan være avhengig av økonomiske ressurser. ${ }^{171}$

I rettslig og administrativ saksbehandling, som omfatter mekling, skal barnet «særlig» gis anledning til å bli hørt, jf. BK art. 12 nr. 2. Barnekomiteen har presisert at separasjon og skilsmisse er blant de viktigste sakene som krever at barnet høres, og at all lovgivning om separasjon og skilsmisse derfor skal ha en bestemmelse som sikrer barnet retten til å bli hørt av beslutningstakere og i meklingsprosesser. ${ }^{172}$

Staten har dermed en klar plikt til å sikre barnets rett til å bli hørt i forbindelse med meklingen i lovgivningen. Det kan derfor stilles spørsmål ved om det er tilstrekkelig at staten har gitt en bestemmelse som pålegger mekleren å informere foreldrene om deres plikt til å høre barna etter bl. $\S 31$, jf. meklingsforskriften $\S 2$.

Ved domstolsbehandling av foreldretvister har dommeren et lovpålagt ansvar for å sikre at barnet blir hørt etter bl. § 31(2), og rett til selv å snakke med barnet eller la en sakkyndig gjøre

\footnotetext{
${ }^{167}$ General Comment No. 5 pkt. 1, General Comment No. 12 pkt. 48, Smith (2012) s. 20

168 General Comment No. 5 pkt. 1, Sandberg (2012) s. 92

${ }^{169}$ General Comment No. 12 pkt. 19

${ }^{170}$ Sandberg (2012) s. 91

${ }^{171}$ Sandberg (2012) s. 92

${ }^{172}$ General Comment No. 12 pkt. 50, 52
} 
det, jf. bl. § 61 nr. 4. Mekler har ingen tilsvarende plikt eller rett. Forskjellen kan begrunnes med at det i meklingen er foreldrene selv som skal treffe avgjørelsen, og ikke mekler. BK art. 5 understreker at foreldrene har primæransvaret for barna, og det kan derfor hevdes å være en inngripen i retten til privat- og familieliv å la andre høre barna uten foreldrenes samtykke i saker der de selv skal treffe avgjørelsen. ${ }^{173}$

På den annen side har staten en generell forpliktelse til å påse at barn oppnår rettighetene de er tilkjent, også innad i familien. ${ }^{174}$ Meklingen ved familievernkontoret er gjort obligatorisk av det offentlige, som et ledd i prosessen frem mot separasjon/skilsmisse og for å kunne reise sak for domstolene. Staten har dermed allerede grepet inn i privatlivet, for å sikre kontroll med at barnets beste blir ivaretatt ved foreldrenes samlivsbrudd. Det er derfor vanskelig å se at de ikke også skal sikre kontroll med barnets uttalerett.

Sandberg har påpekt at myndigheten i forbindelse med oppfyllelsen av art. 12 kan gå foran med et godt eksempel ved å snakke med barnet i alle saker hvor det er aktuelt, og gjøre et nummer ut av dette. ${ }^{175}$ Den obligatoriske meklingsordningen gir staten en særlig mulighet til å sikre at barnet faktisk blir hørt på en arena hvor dette ellers er vanskelig, nemlig i familien.

Samlet tyder derfor mye på at statens lovgivningsmessige forpliktelser etter barnekonvensjonen ville blitt bedre ivaretatt dersom barnet fikk en selvstendig rett til å delta i meklingen, uavhengig av foreldrenes samtykke.

\subsubsection{Avsluttende merknader fra barnekomiteen}

I barnekomiteens avsluttende merknader til Norges fjerde rapport fra 2010 uttalte barnekomiteen at de er betenkt over at barnets rett til å bli hørt ikke er fullt ut implementert i praksis eller effektivt praktisert $\mathrm{i}$ alle faser av prosesser der man treffer beslutninger eller kommer fram til ordninger for barns liv. ${ }^{176}$

Barnekomiteen anbefalte staten å videreføre og styrke arbeidet med å implementere fullt ut art. 12, og fremme behørig respekt for synspunktene til barn i alle administrative og rettslige prosesser, herunder i barnefordelingssaker. Videre anbefalte de at staten fremmer barnets deltakelse, hjelper dem med å utøve denne retten i praksis, og sørger for at det blir tatt behørig hensyn til deres synspunkter i alle forhold som angår dem, blant annet i familien. ${ }^{177}$

\footnotetext{
${ }^{173}$ Søvig (2009) s. 83

${ }^{174}$ Søvig (2009) s. 83

${ }^{175}$ Sandberg (2012) s. 101

${ }^{176}$ Concluding Observations (2010) pkt. 24

${ }^{177}$ Concluding Observations (2010) pkt. 25
} 
Barnekomiteen gir her klare signaler på at barnets rett til å bli hørt ikke er fullt ut ivaretatt i rettslige og administrative prosesser, uten at meklingen er direkte nevnt. I oppfølgingen av barnekomiteens merknader, uttalte imidlertid departementet følgende:

«Det antas å være behov for å lage en egen veileder for høring av barn etter barneloven. Det vil bli arbeidet videre med å sikre at barnets syn kommer fram under meklingen ved familievernkontorene og eksterne meklere, herunder ved at det blir tatt i bruk gode modeller for samtaler med barn». ${ }^{178}$

Dette tilsier at departementet mener barnets rett til å bli hørt ikke er tilstrekkelig ivaretatt i meklingen. Samtidig gir de ikke uttrykk for at det er behov for lovendringer, noe som tyder på at de mener lovgivningen er i samsvar med BK. I flere forarbeider er det på generelt grunnlag uttalt at dagens regelverk oppfyller BK art. 12. Likevel har det til stadighet blitt foretatt endringer i reglene om barnets rett til å bli hørt i domstolene, for at de skal være bedre i samsvar med BK, senest i 2014. ${ }^{179}$ I forarbeidene til disse endringene ble både generell kommentar nr. $12 \mathrm{og}$ barnekomiteens merknader fra 2010 nevnt, men høring av barn i meklingen var ikke et tema. Heller ikke i en utredning fra 2009 om BKs forhold til norsk rett, foretatt i regi av BLD, ble reglene om barnets deltakelse i meklingen tatt opp. ${ }^{180}$ Som gjennomgått i pkt. 4.1, er spørsmålet omtalt i en NOU og en stortingsmelding, men fokuset her ligger på gjennomføringen i praksis, slik som i departementets oppfølging av barnekomiteens merknader.

Selv om tolkningen av BK art. 4 og 12 kan tyde på at staten ikke i tilstrekkelig grad har oppfylt sine lovgivningsmessige forpliktelser når barnets uttalerett i meklingen er gjort avhengig av foreldrenes samtykke, ser det dermed ut til at staten selv mener reglene er tilstrekkelige. Samtidig gir departementet uttrykk for at det er behov for endringer i praksis. Dette gjør det relevant å se på hvordan barnets rett til å bli hørt ivaretas i meklingen i praksis.

\footnotetext{
${ }^{178}$ BLD rapport (2011) s. 13

${ }^{179}$ Prop.85 L (2012-2013) s. 37 flg.

180 Søvig (2009)
} 


\section{Barnets deltakelse i meklingen i praksis}

Som gjennomgått i pkt. 4.1, har mekler etter nasjonale regler kun et ansvar for å informere foreldrene om deres plikt til å høre barnet etter bl. § 31, jf. meklingsforskriften $\S 2$. Det foreligger ingen hjemmel for at mekler selv kan snakke med barnet, men det åpnet for muligheten dersom mekler $\emptyset$ nsker dette og begge foreldrene samtykker. Mekler har likevel ingen lovpålagt plikt til å påse at barnet faktisk høres, og heller ingen journalføringsplikt i meklingene, jf. familievernkontorloven $\S 11(4)$. Det foreligger dermed ingen kontroll med om og eventuelt hvordan barnets uttalerett ivaretas. I senere tid er det imidlertid foretatt flere unders $\varnothing$ kelser som belyser spørsmålet. Jeg vil i det følgende presentere og drøfte relevante resultater fra disse.

\subsection{I hvilken grad høres barn i forbindelse med meklingen?}

I 2011 forelå rapporten fra en landsomfattende evaluering av meklingsordningen foretatt av SINTEF, på oppdrag fra Barne-, likestillings- og inkluderingsdepartementet. Evalueringen ble gjort ved familievernkontorer og blant eksterne meklere. ${ }^{181}$

I evalueringen ble det blant annet unders $\varnothing \mathrm{kt} \mathrm{i}$ hvor stor grad mekler informerer foreldrene om barnets uttalerett, og i hvor stor grad barnets mening er tema i meklingen. ${ }^{182}$

Resultatene viser at mekler ikke hadde informert foreldrene om barnets rett til å bli hørt i $38 \%$ av sakene, mens de ikke hadde informert foreldrene om plikten til å høre barna i $41 \%$ av sakene. ${ }^{183}$ Det ble i mindre grad gitt informasjon om barns uttalerett når barna var under 7 år enn når de var mellom 7 og 16 år. Selv om barn har en absolutt uttalerett fra de er 7 år, har foreldrene plikt til å høre yngre barn som er i stand til å danne seg egne synspunkter. Mekler skal derfor også informere foreldrene om deres plikt til å høre barn under 7 år. ${ }^{184}$

Dette tyder på at mekler i svært mange saker ikke har oppfylt sin lovpålagte informasjonsplikt etter meklingsforskriften $\S 2$.

Likevel hadde mekler i om lag to av tre saker snakket med foreldrene om hva de oppfatter at barna ønsker/tenker. ${ }^{185}$ I $28 \%$ av sakene hadde mekler i stor grad snakket med foreldrene om dette, mens i $37 \%$ av sakene var dette i noen grad et tema. Mekler hadde imidlertid ikke snakket med foreldrene om barnets mening i $16 \%$ av sakene, og i liten grad i $19 \%$ av sakene.

\footnotetext{
181 Ådnanes (2011) s. 34

182 Ådnanes (2011) s. 122-123

183 Ådnanes (2011) s. 122

184 Ådnanes (2011) s. 123

185 Ådnanes (2011) s. 123
} 
Når mekler i flere saker ikke har informert foreldrene om plikten til å høre barna og ikke snakket med foreldrene om barnas meninger, er det vanskelig å vite hvorvidt barna faktisk har blitt hørt.

\subsection{Deltar barn i meklingen?}

Det fremkommer videre av unders $\varnothing$ kelsen fra SINTEF at barn deltar i selve meklingen i kun 4 $\%$ av sakene. ${ }^{186}$

Også flere tidligere unders $\varnothing$ kelser viser at barn deltar i meklingene i svært liten grad. I forrige evaluering av meklingsordningen fra 1996/1997 fremkom det at barn deltok i $2 \%$ av sakene. ${ }^{187}$ I en landsdekkende survey blant meklere foretatt av Smørdal og Thuen i 2004 rapporterte nesten $90 \%$ at de sjelden eller aldri hørte barn i meklingen. ${ }^{188}$

I 2003 ble det i regi av Barne- og familiedepartementet sendt ut et spørreskjema til alle landets meklere der de ble spurt om de hadde barn med i meklingen. Der svarte $17 \%$ at de aldri hadde med barn, mens $70 \%$ svarte at de sjelden hadde med barn. ${ }^{189}$

Til tross for $\varnothing \mathrm{kt}$ fokus den siste tiden på å styrke barnets deltakelse, ser man dermed at dette ikke har ført til særlig økning i barnets direkte deltakelse i meklingen.

\subsection{1 Årsaker til at barn ikke deltar}

Når barn i så liten grad deltar i meklingene, er det interessant å se på hva som er årsakene til dette.

I undersøkelsen fra SINTEF ble meklerne spurt om hvorfor barn over 7 år ikke deltar. ${ }^{190}$ Der svarte $59 \%$ at barnets deltakelse ikke var noe tema i meklingen. I $27 \%$ av sakene hadde foreldre og mekler sammen kommet fram til at barnet ikke skulle delta, mens i $16 \%$ av sakene var det en av foreldrene som ikke ønsket dette (8\% mor og $8 \%$ far). I $2 \%$ av sakene hadde barna blitt spurt om å delta, men takket nei.

Samlet tyder dette på at årsaken til at barnet ikke deltar i de aller fleste tilfellene, er at mekler og/eller foreldrene ikke ønsker det.

\footnotetext{
186 Ådnanes (2011) s. 125

${ }^{187}$ Ekeland (1997) s. 153, se også Ekeland (1996)

${ }^{188}$ Smørdal og Thuen (2004) i Haugen (2010) s. 117

${ }^{189}$ Rød (2010) s. 123

190 Ådnanes (2011) s. 127
} 
Når barnets deltakelse ikke har blitt tatt opp i $59 \%$ av sakene, kan det se ut som at det i stor grad blir tatt for gitt av mekler at barn ikke skal delta. ${ }^{191}$ Samtidig svarte nesten 2 av 3 meklere at de enten var helt enig (22\%) eller delvis enig (42\%) i at alle barn over 7 år på en eller annen måte burde få tilbud om å høres i forbindelse med meklingen. $15 \%$ var imidlertid helt uenige i dette. ${ }^{192}$ Det synes derfor ikke å være samsvar mellom meklernes praksis og hva de fleste egentlig mener om barnets deltakelse.

Mange har spurt seg om grunnen til at barn deltar i så liten grad er at meklerne mangler erfaring med dette. ${ }^{193}$

I studien fra SINTEF fremkom det at de fleste meklere har erfaring med å inkludere barn. ${ }^{194}$ Av de som besvarte spørsmålet, var det bare $7 \%$ som oppga at de aldri har inkludert barn direkte i meklingen. $47 \%$ oppga at de har gjort det noen få ganger, og $46 \%$ at de har gjort det flere ganger.

Samtidig viser flere studier at meklere har behov for $\emptyset \mathrm{kt}$ kompetanse om barns deltakelse. I SINTEF-undersøkelsen svarte $21 \%$ at de i stor grad har behov for mer kompetanse om hvordan involvere barn direkte i meklingen, mens $71 \%$ svarte at de i noen grad hadde behov for dette. Bare $10 \%$ oppga at de ikke hadde behov for dette i det hele tatt. ${ }^{195}$

I spørreskjemaet som ble utsendt i regi av Barne- og familiedepartementet i 2003, svarte $61 \%$ av meklerne at de ville vurdere å ta med barn i mekling dersom de lærte en metode som ivaretok barns interesser og behov. Blant de resterende var $26 \%$ usikre, mens $13 \%$ svarte at de uansett ikke ville ta med barn. ${ }^{196}$

Også undersøkelsen fra Smørdal og Thuen viser at mange er villige til å ta med barn dersom de lærer gode metoder for dette. ${ }^{197}$

\footnotetext{
191 Ådnanes (2011) s. 127

192 Ådnanes (2011) s. 128

193 Ådnanes (2011) s. 127

194 Ådnanes (2011) s. 127

195 Ådnanes (2011) s. 128

${ }^{196}$ Rød (2010) s. 123

${ }^{197}$ Smørdal og Thuen (2004) i Haugen (2010) s. 122
} 
Dette tyder på at noe av grunnen til at meklere ikke inviterer med barn, er at de ikke føler seg kompetente nok til å snakke med barna, men at mange likevel ønsker å gjøre det dersom de lærer gode metoder. Her ligger det derfor et potensial i meklingsordningen for å høre barn. ${ }^{198}$

Imidlertid viser unders $\emptyset$ kelsene at noen meklere uansett ikke ønsker å ta med barn. I SINTEFundersøkelsen ble det gitt uttrykk for at meklers rolle er å bringe barnestemmen inn i meklingen, men ikke å ha barnet fysisk til stede. ${ }^{199}$ I en undersøkelse gjort av Haugen og Rantalaiho påpeker mange meklere også at de opplever tidspress under meklingen, slik at det ikke er tid til å involvere barn. ${ }^{200}$ Det samme har meklere Barneombudet har snakket med gitt uttrykk for. ${ }^{201}$ Dette viser at det kan være ulike grunner til at barn ikke inviteres med.

Når det gjelder foreldrene, viser undersøkelsen fra SINTEF at de aller fleste (71 \%) ikke hadde noe ønske om å ta med barn i meklingen. Samtidig var $12 \%$ helt enig og $9 \%$ litt enig i at barnet skulle delta. ${ }^{202}$ Det er ikke kartlagt hva som er årsaken til foreldrenes skepsis. Forskning fra Australia har imidlertid vist at mange foreldre blander «rett til deltakelse» med «rett til å bestemme», og at de derfor ofte tviler på om barna er kompetente til å delta i slike prosesser. ${ }^{203}$ Dette kan være en mulig forklaring på foreldrenes skepsis til å involvere barn. Uavhengig av årsaken, tyder imidlertid skepsisen på at foreldrene er lite egnet som barnets representant.

Når det i kun $2 \%$ av sakene var barnet selv som takket nei til å delta, ser det ut til at mekler og foreldre i de fleste tilfeller hindrer barnet i å delta i meklingen, uavhengig av hva barnet selv måtte ønske.

\subsection{2 Årsaker til at barn deltar}

Der barn deltar i selve meklingen, er det ulike grunner til dette. En begrunnelse er barnets rett til å påvirke sin livssituasjon gjennom å bli hørt i mekling. Denne begrunnelsen er nærmest knyttet til barnets rett til å bli hørt. ${ }^{204}$ I noen saker tas barn med for å ivareta barnets behov for å snakke med noen om sin livssituasjon «her og nå», og dermed avlaste barna for konfliktene. Motivasjonen her grenser mer over i terapi. ${ }^{205}$ Andre igjen inviterer med barn for å finne ut

\footnotetext{
${ }^{198}$ Haugen (2010) s. 122

199 Ådnanes (2011) s. 124

${ }^{200}$ Haugen (2010) s. 116-117

${ }^{201}$ Barneombudet (2012) s. 33

202 Ådnanes (2011) s. 126

${ }^{203}$ Cashmore (2008) s. 92

204 Ådnanes (2011) s. 124, Tjersland (2010) s. 695

205 Ådnanes (2011) s. 124, Tjersland (2010) s. 695
} 
hvordan barnet har det i situasjonen, for å kunne veilede foreldrene. ${ }^{206}$ I saker hvor konflikten er høy, kan også barn bli inkludert som et virkemiddel for å få bevegelse i saken, og dermed hjelpe foreldrene til å komme videre. ${ }^{207}$ Dette kan bidra til at det ikke blir noen rettssak i det hele tatt.

Dette tilsier at det ofte må være en grunn til å inkludere barn, og denne grunnen er ikke nødvendigvis at det å høre barn er et gode i seg selv. ${ }^{208}$

\subsection{Hvordan høres barn i meklingen?}

I de tilfellene der barn deltar i meklingen, er det ingen ensartet praksis for hvordan høringen gjennomføres. ${ }^{209}$ Dette er naturlig, ettersom det ikke finnes klare retningslinjer for høring av barn.

I perioden 2004-2007 utviklet Familievernkontoret for Asker og Bærum en modell for høring av barn i mekling. Prosjektet ble økonomisk støttet av Barne- og familiedepartementet. ${ }^{210}$ Modellen legger opp til tre møter med to meklere, hvor barnet snakker med mekler uten at foreldrene er til stede.

Første møte er en samtale med foreldre og mekler. I andre møte gjennomføres først en fellessamtale med foreldre, barn og mekler, før meklerne snakker med barnet uten foreldrene til stede. Deretter blir foreldrene informert om barnas synspunkter av den ene mekleren, mens barnet og den andre mekleren sitter bak et enveisspeil. Slik kan barna følge med på hva som blir sagt til foreldrene, og eventuelt korrigere dette gjennom mekleren. Barnet får dermed kontroll på situasjonen og trygghet for at tilbakemeldingene blir gitt i samsvar med egne $\emptyset$ nsker. Etter dette foretas en fellessamtale med hele familien, hvor foreldrene blir bedt om å vurdere det som har kommet fram til den neste timen foreldrene har med mekler. Foreldrene blir også bedt om å ikke diskutere det de har kommet frem til med barna før de igjen møtes på familievernkontoret. Barna står derimot fritt til på eget initiativ å snakke med foreldrene om det de har opplevd under barnehøringen. I tredje møte har mekler en samtale med foreldrene, uten at barna er med. De snakker da om hvordan informasjonen fra barna skal tas hensyn til når foreldrene skal bestemme bosted og samvær. ${ }^{211}$

\footnotetext{
206 Tjersland (2010) s. 695

${ }^{207}$ Haugen (2010) s. 118-119, Tjersland (2010) s. 695

${ }^{208}$ Haugen (2010) s. 119

209 Ådnanes (2011) s. 128, Tjersland (2010) s. 695

${ }^{210} \operatorname{Rød}(2010)$ s. 116

${ }^{211}$ Ribe-Anderssen m.fl. (2007) i Rød (2010) s. 120-121
} 
En undersøkelse gjort av Familievernkontoret i Molde i 2010 viser at denne modellen er tatt i bruk ved flere av landets familievernkontorer. ${ }^{212}$ Av de 49 kontorene som besvarte henvendelsen, svarte 30 kontorer at de bruker modellen, derav 24 i stor grad og 6 i liten grad. 19 kontorer svarte at de ikke bruker modellen, men de fleste sa at de hadde god kjennskap til den. Ved ett kontor svarte de at de ikke bruker modellen, fordi de ønsker større handlingsrom i møte med ulike problemstillinger. Et annet kontor sa at de har gjort det til en rutine og informere foreldrene om at de alltid ønsker å snakke med barna når foreldrene er i konflikt.

Imidlertid var det også noen kontorer som sa at de hører barn ved bruk av andre metoder.

Noen svarte at de tar utgangspunkt i psykolog Øvreeides bok om samtaler med barn i vanskelige livssituasjoner. Han beskriver blant annet fem viktige grunnprinsipper i den utviklingsstøttende dialogen. ${ }^{213}$

Noen få kontorer svarte at de tar utgangspunkt i boka Samlivsbrudd og foreldreskap av psykolog Tjersland. Her refereres det til en del spørsmål som ble stilt til barn, som del av en meklingsundersøkelse. ${ }^{214}$

\subsection{Erfaringer med og betydningen av barnets deltakelse}

Til tross for skepsis blant meklere og foreldre til å inkludere barn i meklingen, samt variasjoner i hvordan høringen gjennomføres, viser flere undersøkelser at de som har erfaring med at barn deltar, i stor grad er fornøyde.

I unders $\varnothing$ kelsen fra SINTEF mente nesten $80 \%$ av foreldrene i saker der barnet hadde deltatt at barnet snakket fritt. De fleste, $86 \%$, mente at barna ble ivaretatt på en god måte i meklingen. Imidlertid var $22 \%$ helt og $14 \%$ litt enig i at det var uheldig at barnet deltok i meklingen. $^{215}$

I en survey fra 2007 foretatt blant meklere og foreldre som har benyttet modellen utviklet ved Familievernkontoret for Asker og Bærum, fant man at det store flertallet var godt fornøyde med modellen. ${ }^{216} 85 \%$ av meklerne mente at modellen bidro til at foreldresamarbeidet ble bedre, og $71 \%$ av foreldrene mente det var viktig for barnet å delta i barnehøringen. Så godt som alle foreldrene som deltok, følte at barnet ble godt ivaretatt under høringen, og $87 \%$ av foreldrene vil anbefale andre å benytte seg av tilbudet.

\footnotetext{
${ }^{212} \operatorname{Rød}(2010)$ s. 122

${ }^{213} \operatorname{Rød}(2010)$ s. 122, Øvreeide (2009)

${ }^{214}$ Rød (2010) s. 123, Tjersland (1992)

215 Ådnanes (2011) s. 126

${ }^{216}$ Ribe-Anderssen m.fl. (2007) i Ådnanes (2011) s. 125
} 
Det fremkommer i en unders $\varnothing$ kelse fra 2007 blant meklere i hele landet (63 respondenter) at $64 \%$ i noen eller større grad inviterte med barn etter at de hadde fått kjennskap til modellen utviklet ved Familievernkontoret for Asker og Bærum. $31 \%$ svarte at de like mange ganger inviterte med barn, og kun $5 \%$ svarte færre ganger. ${ }^{217}$ Også dette kan tyde på at manglende kompetanse hos meklere er en viktig grunn til at barn sjelden blir invitert med.

Blant foreldrene som har erfaring med at barn deltar, viser også undersøkelsen fra SINTEF at om lag 3 av 4 var enten helt enig (42\%) eller litt enig (32\%) i at barnets tilbakemelding hadde direkte betydning for avtalen. ${ }^{218}$ I surveyen fra 2007 om høring av barn i modellen fra Asker og Bærum, sier $62 \%$ av foreldrene at barnehøringen førte til en avtale mer i retning av barnets $\emptyset$ nsker. ${ }^{219}$ Det kan dermed se ut til at barnets deltakelse ikke bare bidrar til at barnet blir hørt, men også til at meningen blir vektlagt.

${ }^{217}$ Ribe-Anderssen m.fl. (2007) i Rød (2010) s. 123

218 Ådnanes (2011) s. 126

${ }^{219}$ Ribe-Anderssen m.fl. (2007) i Ådnanes (2011) s. 126 


\section{Rettspolitiske betraktninger om barnets deltakelse i meklingen}

Gjennomgangen av praksis viser at det er svært varierende både om og hvordan barnets rett til å bli hørt ivaretas i meklingen, og at meklers og foreldres individuelle vurderinger er avgjørende for om retten oppfylles eller ikke. Mye tyder på at utarbeiding av gode modeller for høring av barn er nødvendig, slik departementet har foreslått (pkt. 4.6.3). Samtidig ser det ikke ut til at dette er tilstrekkelig til å sikre at barnets syn kommer fram under meklingen. Det kan derfor se ut som det er behov for endringer i reglene om høring av barn i meklingen.

I rapporten fra SINTEF er det påpekt at det ligger et stort potensial i å sikre at meklere følger sin lovpålagte informasjonsplikt. ${ }^{220}$ Det foreslås at det bør fremkomme mer eksplisitt i rundskrivet, samt etableres i praksis at mekler i alle saker skal sikre seg at foreldrene har snakket med barna, eller i saker der barna er svært små, diskutert hvilke implikasjoner den ordningen de kommer fram til har for barna. ${ }^{221}$ Også Ekeland har hevdet at mekler bør gjøre mer enn å følge opp informasjonsplikten sin, blant annet ved å snakke med foreldrene om hvordan man prater med barna, og hvordan man kan vurdere det barna sier. ${ }^{222}$

Imidlertid er en oppfyllelse av informasjonsplikten ingen garanti for at foreldrene faktisk hører barnet eller tar hensyn til barnets mening. Den rettsdogmatiske analysen i pkt. 4 tilsier at retten til å bli hørt vil bli best ivaretatt dersom barnet høres av mekler. Også erfaringene fra barnets deltakelse i praksis kan indikere dette.

Spørsmålet om barnets deltakelse i meklingen, er imidlertid ikke utelukkende et spørsmål av juridisk karakter. Blant norske fagpersoner foregår det en kontinuerlig debatt om hvorvidt barn bør delta i meklingen eller ikke. ${ }^{223}$ Synene er svært delte, noe som viser at temaet er kontroversielt. Jeg vil i det følgende redegjøre nærmere for sentrale argumenter i debatten.

\subsection{Bør barn delta i meklingen?}

\subsubsection{Debatten blant fagpersoner}

Mekling er først og fremst en kommunikasjonsprosess mellom foreldrene, der meklerens rolle er å legge forholdene til rette for konstruktiv dialog. ${ }^{224}$ Samtidig skiller familiemekling seg fra andre former for mekling, fordi den gjelder en person som oftest ikke er til stede i prosessen. Dette gjør at spørsmålet om barn bør være med i meklingen står sentralt. ${ }^{225}$

\footnotetext{
220 Ådnanes (2011) s. 123

221 Ådnanes (2011) s. 144

222 Ekeland (1994) s. 33

${ }^{223}$ Bla. Haugen (2010) s. 117, Nordhelle (2007) s. 125

${ }^{224}$ Nordhelle (1999) s. 47

${ }^{225}$ Nordhelle (2007) s. 121
} 


\subsubsection{Argumenter mot}

\subsection{Foreldrenes ansvar}

Et av hovedargumentene mot å involvere barn i mekling, er at dette er en sak mellom foreldrene og et voksenansvar som barn bør fritas for. ${ }^{226}$

Omfattende forskning har dokumentert at sterke og vedvarende konflikter mellom foreldrene er noe av det som skaper størst problemer for barn ved samlivsbrudd. Hvis foreldrene ikke klarer å skjerme barna fra konflikten, kan det føre til betydelige psykiske problemer for barna. ${ }^{227} \AA$ trekke barn inn i meklingen, er en direkte involvering i saken, og mange mener derfor at barn ikke bør delta. ${ }^{228}$

Hvis barnet deltar i meklingen, er det også fare for at barnet vil oppleve et ubehagelig press til å snakke om eller ta stilling til noe det ikke ønsker. ${ }^{229}$ Spørsmålene om barnets bosted og samvær etter samlivsbrudd, kan være svært vanskelige tema både for barnet og foreldrene. Det kan derfor være belastende for barnet å skulle mene noe om dette. ${ }^{230}$ Hvis barnet blir spurt direkte om disse spørsmålene i meklingen, vil mange også lett oppleve at ansvaret legges på deres skuldre. ${ }^{231}$

Det er også hevdet at barn ikke bør være til stede i meklingen fordi det kan hindre foreldre og mekler i å snakke om «voksentemaer», og at det kan være problematisk for mekler å opprettholde sin nøytrale posisjon hvis de samtidig skal ivareta barna i situasjonen. ${ }^{232}$

\subsection{Fare for lojalitetskonflikt}

Et annet argument mot å involvere barn i meklingen, er at barn kan komme i en lojalitetskonflikt der de føler de må velge mellom foreldrene. ${ }^{233}$

Barn er glad i begge sine foreldre, og de kan føle at de svikter den ene når de velger den andre. Mange barn vil derfor ikke sin noe om hvem de vil bo hos, selv om de egentlig har et

\footnotetext{
${ }^{226}$ Haugen (2010) s. 117

${ }^{227}$ Galtung (1998) s. 124, Ot.prp.nr. 103 (2004-2005) s. 16

${ }^{228}$ Nordhelle (2007) s. 132, NOU 1998:17 s. 45

${ }^{229}$ Gulbrandsen (2010) s. 711-712

${ }^{230}$ Barneombudet (2012) s. 25

${ }^{231}$ Nordhelle (1999) s. 48

232 Ekeland (1994) s. 253

${ }^{233}$ Haugen (2010) s. 117, NOU 1998:17 s. 45
} 
$\emptyset$ nske. ${ }^{234}$ Ved å bli trukket inn i meklingen, er det fare for at barnet føler seg presset til å uttale seg, og barnet kan dermed settes i et voldsomt krysspress. ${ }^{235}$

Dette presset kan også innebære en risiko for at barnet velger en av sine foreldre av andre grunner enn sine egne behov. ${ }^{236}$ Barnet kan bli manipulert i sitt valg, eller velge den av foreldrene det synes mest synd på. Andre ganger kan barnet være sint på den ene og velge den andre som «straff». Barnet kan imidlertid også være redd for reaksjonene til den ene av foreldrene, og derfor velge denne.

\subsection{Barna kan få for mye makt}

Et tredje argument mot å la barn delta i meklingen, er at det innebærer en fare for at barnet kan få for mye makt i situasjonen. ${ }^{237}$

Som vist over, gir ikke alltid barn uttrykk for sin egen mening, og de kan derfor være ustabile informanter. De kan også endre mening gjennom prosessen. Dette gjelder særlig små barn, som kan ha vanskelig for å vurdere sine interesser i et lengre perspektiv. Dersom barn deltar i meklingen, er det en fare for at deres meninger kan bli tillagt større vekt enn de bør. ${ }^{238}$

\subsubsection{Argumenter for}

På den annen side er det et økende fokus fra sentrale politikere og fagfolk på betydningen av å trekke barn direkte med i spørsmål omkring deres liv, også i mekling. ${ }^{239}$ Senest i september ble det holdt en konferanse om barns rettssikkerhet etter samlivsbrudd, hvor alle ekspertene var enige om at barna må få sin egen time på familievernkontoret. ${ }^{240}$ Det er hevdet at dersom barn ikke deltar i meklingen, blir de i stor grad uten innflytelse på helt sentrale spørsmål for barnet. $^{241}$

\subsection{Få kjennskap til barnets meninger og behov}

Et av argumentene for at barn bør delta i meklingen, er at det er viktig for å få vite hva barnet faktisk mener, og hvordan barnet har det. ${ }^{242}$

\footnotetext{
${ }^{234}$ Nordhelle (1999) s. 48

235 Barneombudet (2012) s. 25

${ }^{236}$ Nordhelle (1999) s. 48, Nordhelle (2007) s. 132

${ }^{237}$ Guldbrandsen (2010) s. 712

${ }^{238}$ Nordhelle (2007) s. 132

${ }^{239}$ Haugen (2010) s. 117, Nordhelle (2007) s. 125

240 «Den viktigste stemmen» (2014)

${ }^{241}$ NOU 1998:17 s. 45

${ }^{242}$ Langballe (2006) s. 34, Nordhelle (2007) s. 130
} 
I senere tid har det vokst fram et positivt syn på barnets forutsetninger for å komme med informasjon om vanskelige temaer i livet sitt. ${ }^{243}$ I dette synet ligger at barnet sitter inne med kunnskap om sin egen livssituasjon, som voksne ikke har automatisk kjennskap til. Man ser dermed på barnet som et subjekt, med egne følelser, opplevelser, ønsker og drømmer. For å få vite noe om hvordan barnet har det, må man derfor snakke med barnet selv.

Forskning viser videre at halvparten av foreldrene i meklingsprosessen er uenige om hva som er barnets behov, og at foreldre i konflikt ofte har vanskelig for å skille egne behov fra barnets. ${ }^{244}$ Tidligere forskning har også vist at barns opplevelse av skilsmissen og nye familieformer kan skille seg fra foreldrenes syn, og at det derfor er viktig å lytte til barn. Ethvert barn og enhver familiesituasjon er unik, og barns perspektiver tilfører viktig og verdifull kunnskap om situasjonen. ${ }^{245}$

\subsection{Barnets behov for å bli sett og forstått}

Et annet argument for å la barn delta i meklingen, er barnets behov for å bli sett og forstått i forbindelse med foreldrenes samlivsbrudd. ${ }^{246}$

Foreldre i konflikt kan være mer opptatt av konflikten seg imellom og ivaretakelsen av egne behov, fremfor barnets behov. Barnet kan i denne situasjonen oppleve at ingen forstår det, og det kan være svært vanskelig for barnet å ikke bli møtt på slike grunnleggende behov. ${ }^{247}$ Hvis barnet tas med i meklingen, kan mekler vise barnet forståelse, og hjelpe barnet med å uttrykke sine følelser og behov overfor foreldrene. ${ }^{248}$

\subsection{Barnets ønske om å uttale seg}

Et tredje argument for at barn bør delta i meklingen, er barnets eget ønske om å uttale seg i spørsmål som angår dem.

Både norsk og internasjonal forskning dokumenterer at barn ikke nødvendigvis vil være med på å ta den endelige avgjørelsen om bosted og samvær, fordi dette er de voksnes ansvar. Det betyr imidlertid ikke at barn ikke er kompetente eller ikke vil bli hørt. ${ }^{249}$ Forskning om barns medvirkning viser at barn gjerne vil ha både informasjon og selv få mulighet til å si sin me-

\footnotetext{
${ }^{243}$ Langballe (2006) s. 34

${ }^{244}$ Nordhelle (2007) s. 127

245 Haugen (2010) s. 122

${ }^{246}$ Nordhelle (2007) s. 128-129

${ }^{247}$ Nordhelle (2007) s. 128

${ }^{248}$ Nordhelle (2007) s. 130

${ }^{249}$ Haugen (2010) s. 125, Skjørten (2010) s. 105, Cashmore (2008) s. 92
} 
ning. ${ }^{250}$ Når barn gis anledning til å uttale seg i foreldretvister for domstolene, velger de fleste å benytte seg av denne muligheten. Kun unntaksvis fremgår det av dommene at barn har takket nei til å fremme sine synspunkter om bosted og samvær. ${ }^{251}$ Også Barneombudets inntrykk er at barn ønsker å bli sett og få anledning til å komme med sine erfaringer og synspunkter i trygge rammer. Det er samtidig ikke alltid lett å si ting direkte til foreldrene, og det kan derfor være godt å få hjelp fra en nøytral tredjeperson. ${ }^{252}$

\subsubsection{Oppsummering}

Det kan sies at argumentasjonen både for og imot å inkludere barn i meklingen baserer seg på ulike grunnleggende syn på barnet. ${ }^{253}$ Mens skeptikerne fokuserer på det sårbare barnet som trenger beskyttelse, tar tilhengerne utgangspunkt i det kompetente barnet som har rett til å delta. Flere har fremhevet at det foreligger et spenningsfelt mellom disse to synene. ${ }^{254}$ Når fagpersoner vurderer om barn bør delta i meklingen, ser det ut som at disse to synene blir bæreelementer i en vurdering av hva som er «barnets beste». «Barnets beste» fremstår slik som et overordnet prinsipp i debatten om hvorvidt barn bør delta i meklingen eller ikke. ${ }^{255}$

\subsubsection{Drøftelse}

Samlet kan det se ut som at årsakene til at barn ikke gis rett til å delta i meklingen, eller i så liten grad involveres i praksis, er sammensatte. Mye tyder på at mange meklere ikke anser seg kompetente til å inkludere barn, at de ikke ønsker dette eller ikke føler meklingen gir tid til det, mens det er sannsynlig at foreldrene ikke vil at barn skal delta fordi de blander «rett til deltakelse» med «rett til å bestemme». I tillegg er mange fagpersoner skeptiske fordi de mener det ikke er til «barnets beste» å delta. Barnets rett til å bli hørt blir dermed avhengig av de voksnes individuelle vurderinger.

Selv om det ikke er vanskelig å forstå de ulike argumentene mot å la barn delta, synes denne tankegangen å være problematisk i forhold til BK art. 12. Som tidligere drøftet, fremstår barnekomiteen klar på at uttaleretten ikke kan settes til side av hensyn til barnets beste. Barnekomiteen har også fremhevet at et viktig ledd i gjennomføringen av BK art. 12 er å gi ulike faggrupper god opplæring i barnets rettigheter og hvordan man kan snakke med barn, og at det må settes av tilstrekkelig med tid og ressurser til gjennomføringen. Å gi barnet en rett til å delta, innebærer heller ingen plikt for barnet til å uttale seg. Og dersom barnet ønsker å uttale

\footnotetext{
${ }^{250}$ Skjørten (2010) s. 105

${ }^{251}$ Skjørten (2014) s. 79-80

${ }^{252}$ Barneombudet (2012) s. 31

${ }^{253}$ Haugen (2010) s. 125

${ }^{254}$ Haugen (2010) s. 126

${ }^{255}$ Haugen (2010) s. 125
} 
seg, trenger det ikke ha noen mening om hva løsningen skal være. Poenget med uttaleretten er ikke at barnet skal bestemme, men at det kan komme med synspunkter om noe som kan ha betydning for avgjørelsen. ${ }^{256}$

Barnekomiteen er også klar på at «barnets beste» ikke kan bli tilstrekkelig ivaretatt dersom retten til å bli hørt ikke respekteres. Formålet med meklingen er at foreldrene skal få hjelp til å komme fram til en avtale om foreldreansvar, fast bosted og samvær som er til «barnets beste», og mekler har en lovfestet plikt til å hjelpe foreldrene med dette. Både den rettsdogmatiske drøftelsen, gjennomgangen av praksis, og argumentene blant fagpersoner for å la barn delta, tyder på at barnets rett til å bli hørt vil bli best ivaretatt dersom mekler hører barnet, og ikke foreldrene. Dette blant annet fordi det er en fare for at foreldrene ikke vil formidle barnets syn korrekt, og for at barnets egentlige meninger og behov ikke vil komme fram. I tillegg har man ingen garanti for at foreldrene faktisk hører barnet når disse har alt ansvar. Barnets deltakelse i meklingen kan også gjøre det lettere for både mekler og foreldre å holde fokus på barnet, og bidra til å se hva som er til det beste for akkurat dette barnet. ${ }^{257}$

Ut fra lovgivers forutsetning om at en avtaleløsning mellom foreldrene er det beste for barnet i saker etter barneloven, synes det også noe motstridende at barnets rett til å bli hørt skal bli dårligere ivaretatt i meklingen enn når sak er reist for domstolen. Unders $\varnothing$ kelsen fra SINTEF viser at $75 \%$ av meklingssakene endte i avtale. ${ }^{258}$ Dette er svært positivt. Samtidig vil det i disse tilfellene ikke være noen mulighet for barnet til senere å få overprøvd avtalen. I forbindelse med en rettssak kan den tapende part kreve saken behandlet på ny på grunn av saksbehandlingsfeil dersom barnet ikke er hørt. ${ }^{259}$ Som Sandberg har uttalt, vil avtalen man eventuelt kommer fram til ved mekling, være av like stor betydning for barnet som en avgjørelse truffet av retten, og det er derfor «vanskelig å se at barnet akkurat i denne situasjonen ikke skulle ha rett til å ha et ord med i laget». ${ }^{260}$

Det er til stadighet et $\varnothing \mathrm{kt}$ fokus på å styrke barneperspektivet i saker etter barneloven, blant annet gjennom barnets deltakelse. Sett ut fra et barneperspektiv vil barn ikke bli likeverdige deltakere med reell uttalerett før deres perspektiver og opplevelser blir like selvfølgelig som fokuset på de voksnes perspektiver og opplevelser. ${ }^{261}$ Det er ingen tvil om at det ligger et stort potensiale i dagens meklingsordning i forhold til å ivareta barnets uttalerett.

\footnotetext{
${ }^{256}$ Nordhelle (1999) s. 48

${ }^{257}$ Barneombudet (2012) s. 30

258 Ådnanes (2011) s. 47

${ }^{259}$ Skjørten (2014) s. 79

${ }^{260}$ Sandberg (2008) s. 89

${ }^{261}$ Haugen (2010) s. 126-127
} 
Utfordringen ligger i å sikre barnets rett til deltakelse, uten at dette går på bekostning av barnets beste og barnets behov for beskyttelse. Det vil være mulig dersom foreldre og fagpersoner klarer å lage barnevennlige rammer rundt meklingsinstitusjonen, uten at det skjer en ansvarsforskyvning fra voksne over på barn. ${ }^{262}$ På den måten kan barnet gis mulighet til å snakke om vanskelig temaer på en mest mulig skånsom måte. ${ }^{263}$ Slik kan man ivareta både barnets rett til deltakelse og barnets behov for beskyttelse.

\subsection{Hvordan bør barn høres?}

Det følger av det som er sagt over, og av BK art. 3 og bl. § 48, at dersom barnet skal delta i meklingen, er det svært viktig at dette skjer på en måte som er til «barnets beste». I tråd med barnekomiteens anbefalinger må gjennomføringen være barnevennlig og tilpasset det enkelte barn (pkt. 4.4).

En helt grunnleggende forutsetning i alle tilfeller er at barnet får nødvendig og tilstrekkelig informasjon i forkant av høringen (se pkt. 4.4.2). Barnet må forberedes på det som skal skje, få vite at det ikke skal ta det endelige valget, at det ikke har plikt til å si noe, men kan uttale seg om det det selv ønsker. ${ }^{264}$ Brosjyren «Hva med min mening da?», som er utgitt av departementet, kan her være til hjelp. ${ }^{265}$ Denne er rettet mot barn, og informerer om deres rett til å bli hørt ved samlivsbrudd. Ved Familievernkontoret i Molde har de laget et informasjonsbrev til barna, som på en enkel måte beskriver hva som skal skje under høringen, hvem barna får møte og omtrent hvor lenge samtalen skal vare. ${ }^{266}$

Det er videre viktig at foreldrene i forkant av samtalen forpliktes til ikke å påvirke barna, verken før eller etter samtalen. ${ }^{267}$

\subsubsection{Samtalemetodikk}

Selve samtalen med barna må alltid innledes med kontaktetablering med mekler, slik at barnet får tillitt og føler seg trygg. Dette er en forutsetning for at barnet skal dele sine synspunkter. ${ }^{268}$

\footnotetext{
${ }^{262}$ Haugen (2010) s. $126-127$

${ }^{263}$ Nordhelle (2007) s. 132

264 Tjersland (2010) s. 695

${ }^{265}$ Brosjyre Q-1070

${ }^{266} \operatorname{Rød}(2010)$ s. 126

267 Tjersland (2010) s. 695

268 Nordhelle (2007) s. 137, Barneombudet (2012) s. 25
} 
Det er videre helt sentralt at høringen gjennomføres på en måte som er minst mulig belastende for barnet. Både av barnekomiteen og i norsk sammenheng er det fremhevet at høringen bør skje som en samtale, og ikke som en enveis utspørring (se pkt. 4.4.2). Departementet har utgitt en artikkelsamling om samtaler med barn i saker etter barneloven. ${ }^{269}$ Her presenterer blant annet Langballe og Gamst en dialogisk samtalemetodikk, som i dag brukes både i dommeravhør av barn, ved asylintervju og i barnevernet. ${ }^{270}$ Hensikten er å få barn til å fortelle sine meninger mest mulig fritt og åpent, uten at voksne avsporer eller avbryter. ${ }^{271}$ Informasjonen som har fremkommet mest mulig fritt, er både mest omfattende i sitt innhold og mest pålitelig. I tillegg setter en dialogisk fremgangsmåte barnet i sentrum. ${ }^{272}$

Samtalen bør også skje på en terapeutisk måte, som gir barnet en forståelsesfull og støttende opplevelse. ${ }^{273}$ Det kan her være hjelp å finne i veilederen «Snakk med meg!» om høring av barn i barnevernet, som blant annet presenterer den utviklingsstøttende dialogen. ${ }^{274}$

\subsubsection{Ulike modeller}

Når det gjelder selve strukturen for samtalen, finnes det i praksis tre hovedveier man kan følge. ${ }^{275} \mathrm{Jeg}$ vil i det følgende gjennomgå disse, og gi eksempler på modeller.

\subsection{Individuelle barnesamtaler}

En av mulighetene er at barnet snakker med mekler alene, og at mekleren deretter formidler barnets mening til foreldrene. ${ }^{276}$

Fordelen med denne modellen er at barnet kan snakke fritt uten å måtte ta hensyn til hvordan foreldrene reagerer på det barnet sier. Hvis foreldrene er til stede under samtalen, vil barnet kunne tilpasse sine uttalelser etter foreldrenes ikke-verbale reaksjoner. Det er derfor større sannsynlighet for at mekleren lykkes med å få barnets egentlige mening dersom man snakker med barnet alene. ${ }^{277}$

\footnotetext{
${ }^{269}$ Artikkelsamling Q-1106

${ }^{270}$ Langballe (2006), Barneombudet (2012) s. 27

${ }^{271}$ Langballe (2006) s. 35, 40, 41

272 Barneombudet (2012) s. 27

${ }^{273}$ Nordhelle (2007) s. 131

${ }^{274}$ Veileder Q-1156 s. 16 flg.

275 Tjersland (2010) s. 695, Nordhelle (2007) s. 134-136

${ }^{276}$ Nordhelle (2007) s. 134

${ }^{277}$ Nordhelle (2007) s. 134
} 
En ulempe med modellen kan imidlertid være at barnet i etterkant føler seg illojal overfor den ene eller begge foreldrene, og blir engstelig for hva det har sagt og hva foreldrene får vite. Det er derfor viktig at mekleren er tydelig overfor barnet på hva som skal videreformidles. ${ }^{278}$

Sandberg legger stor vekt på at det bør utvikles gode modeller for høring av barn som gjør at barnet kan føle seg trygg i samtalesituasjonen uten at foreldrene er til stede, slik at barnet kan uttrykke seg «fritt» (se pkt. 4.4.1). Også internasjonalt er dette oppfatningen blant de fleste forskere på feltet. ${ }^{279}$

I New Zealand har det blitt prøvd ut en meklingsmodell hvor barna snakket med mekler alene, og mekler deretter formidlet barnets syn til foreldrene uten barnet til stede. Det ble gjort klart overfor barnet hva som skulle bli videreformidlet. Til slutt ble det holdt et møte med hele familien og mekler, hvor de drøftet gjennomføringen av en konkret plan og andre sentrale spørsmål. ${ }^{280}$ Modellen ble prøvd ut blant 17 familier med totalt 26 barn i alderen 6-18 år. ${ }^{281} \mathrm{I}$ en oppfølgingsstudie en måned senere uttrykte både barn og foreldre at barnet bedre tilpasset seg situasjonen etter at barnet hadde fătt delta og blitt lyttet til av foreldrene, og foreldrene fortsatte å involvere barn i alle endringer av ordningene. ${ }^{282}$ Mange barn fremhevet at kommunikasjonen hadde blitt bedre, og at barna lettere kunne uttrykke sine meninger overfor foreldrene også etter at meklingen var over. ${ }^{283}$

\subsection{Samtale med foreldrene til stede}

En annen metode er at mekleren snakker med barnet sammen med resten av familien. Mekleren har ledelsen, og hjelper barnet der det har behov for det. ${ }^{284}$

Psykologspesialist Øvreeide anbefaler denne metoden i de fleste samtaler med barn etter barneloven, på grunn av barnets sterke avhengighet til foreldrene. ${ }^{285}$ Fordelen med en slik modell, er at foreldrene kan høre direkte hva barnet sier. Dette kan ha større påvirkningskraft på foreldrene enn når mekleren formidler barnets syn. Ved bruk av en slik modell kan mekleren også hjelpe barnet med å uttrykke sine reaksjoner, ønsker og behov overfor foreldrene, og

\footnotetext{
${ }^{278}$ Nordhelle (2007) s. 134, Øvreeide (2006) s. 22

${ }^{279}$ Goldson (2006) s. 9

${ }^{280}$ Goldson (2006) s. 9

${ }^{281}$ Goldson (2006) s. 4

${ }^{282}$ Goldson (2006) s. 16

${ }^{283}$ Goldson (2006) s. 12

${ }^{284}$ Nordhelle (2007) s. 134

${ }^{285} \varnothing$ vreeide (2006) s. 22
} 
hjelpe foreldrene til virkelig å lytte til barnet. ${ }^{286}$ Samtidig er det fare for at barnet ikke får uttrykke seg fritt.

\subsection{Barnesamtale og fellessamtale}

En tredje variant er at mekler først snakker med barnet alene. Deretter tas barnet med i en fellessamtale hvor mekleren alene eller sammen med barnet formidler barnets meninger til foreldrene. Eventuelt blir det en fellessamtale med alle som en oppfølging av formidlingen fra enesamtalen med barnet. ${ }^{287}$

Modellen utviklet ved Familievernkontoret for Asker og Bærum er et eksempel på denne metoden. Her intervjues barnet uten foreldrene til stede, mens tilbakemeldingen til foreldrene skjer med barnet og en mekler bak et enveisspeil (se pkt. 5.3). Ifølge Nordhelle henter denne modellen på mange måter det beste fra to ulike modeller, men ulempen er at den er tid- og ressurskrevende. ${ }^{288}$ Dette fordi den legger opp til bruk av to meklere og tre møter. Nordhelle påpeker at det ikke alltid er behov for en såpass omfattende modell, men at den i utfordrende saker ganske sikkert vil være den mest tjenlige. ${ }^{289}$

\subsection{Hvordan kan meklingsordningen bedre tilrettelegges for barns deltakelse?}

Dersom det skal tilrettelegges for barns deltakelse i meklingen, følger det av det som er gjennomgått at det kan være behov for endringer i dagens meklingsordning.

\subsubsection{Lovfestet rett}

For å sikre alle barn en lik rett til å delta i meklingen, bør retten lovfestes. Dette kan for eksempel gjøres ved å gi mekler plikt til å invitere med barn, slik Barneombudet har foreslått. ${ }^{290}$ Uten en slik lovhjemmel, viser gjennomgangen av praksis at barns muligheter til å delta vil bero på meklers og foreldres individuelle vurderinger. En lovfesting kan derfor hindre en potensiell urettferdighet ved ivaretakelsen og praktiseringen av barnets rett til å bli hørt i meklinger på familievernkontorene. ${ }^{291}$

\subsubsection{Meklers kompetanse}

Mye tyder videre på at meklere må gis økt kompetanse i å snakke med barn, samt opplæring i ulike modeller. Det er viktig at mekler har kjennskap til og erfaring med flere modeller, slik at

\footnotetext{
${ }^{286}$ Nordhelle (2007) s. 134, Øvreeide (2006) s. 22-23

${ }^{287}$ Nordhelle (2007) s. 136

${ }^{288}$ Nordhelle (2007) s. 136

${ }^{289}$ Nordhelle (2007) s. 136

${ }^{290}$ Barneombudet (2012) s. 32

${ }^{291}$ Haugen (2010) s. 124
} 
de i hver enkelt sak kan ta i bruk den mest hensiktsmessige. ${ }^{292}$ Ettersom alle meklere må gjennom obligatorisk opplæring, er det her gode muligheter for å bygge inn høring av barn som ett av elementene. Dette vil også være godt i samsvar med barnekomiteens anbefalinger for gjennomføringen av BK art. 12.

\subsubsection{Tidsrammer}

Det er også tvilsomt om tidsrammene for meklingen er tilstrekkelige til å inkludere barn. I dagens ordning er det obligatorisk for foreldrene å møte til en time mekling, mens det totale tilbudet er på 7 timer. I løpet av den første timen har mekler en rekke lovpålagte oppgaver, og flere meklere har gitt uttrykk for at de opplever tidspress (pkt. 5.2.1). Selv om foreldrene kan tilbys inntil 6 timer mekling til, ble $61 \%$ av alle meklingssakene i 2013 avsluttet etter den første timen. ${ }^{293}$ Med tanke på foreldrenes skepsis til å inkludere barn i meklingen, er det tvilsomt at de frivillig vil være interessert i å møte til flere meklingstimer for at barn skal kunne delta.

Det bør derfor vurderes å øke de obligatoriske timene, noe flere fagpersoner har foreslått. ${ }^{294} \mathrm{I}$ 2007 ble disse redusert fra tre timer til en time, for å skreddersy meklingsordningen inn mot høykonfliktsakene (se pkt. 3.2.1). Dersom barn skal delta, vil det imidlertid være behov for mer tid uavhengig av konfliktnivået i saken. Dette særlig sett hen til viktigheten av at det tas $i$ bruk gode modeller i samtalene. En mulighet kan være å gjøre det obligatorisk med flere timer mekling der barn ønsker å delta, mens man i andre saker kan beholde dagens ordning med en obligatorisk time. Dette vil være i tråd med barnekomiteens anbefalinger om å sette av tilstrekkelig med tid og ressurser i gjennomføringen av BK art. 12.

\footnotetext{
292 Nordhelle (2007) s. 136

293 SSB (2014)

${ }^{294}$ Bla. Barneombudet (2012) s. 33
} 


\section{Avslutning}

Denne oppgaven har hatt til formål å vurdere om den norske meklingsordningen i tilstrekkelig grad ivaretar barnets rett til å bli hørt etter BK art. 12 .

Samlet tyder mye på at barn høres i langt mindre grad enn det er grunnlag for i forbindelse med meklinger på familievernkontoret. Fremstillingen tilsier at barnets rett til å bli hørt vil bli best ivaretatt dersom barnet høres direkte av mekler, og barn selv gir også uttrykk for at de $\emptyset$ nsker å delta i prosessen og bli hørt. Likevel er både foreldre og meklere tilbakeholdne med å involvere barn i selve meklingen. Det ser ut til at mangel på informasjon om hva uttaleretten innebærer, mangel på kompetanse i å snakke med barn og mangel på tid kan være medvirkende årsaker til dette.

Barnets rett til å bli hørt er blant de viktigste rettighetene i barnekonvensjonen, og helt sentral i anerkjennelsen av barnet som eget rettssubjekt. Samtidig er oppfyllelsen av retten fullt og helt avhengig av at staten og de voksne legger forholdene til rette. Ved å gi barn en selvstendig rett til å delta i meklingen, kan staten styrke både barns rettsstilling og barneperspektivet i foreldretvister. Dette vil være godt i samsvar med forpliktelsene etter barnekonvensjonen og lovgivers intensjoner. 


\section{Litteraturliste}

\section{LOVER}

\section{Norske lover og forskrifter}

1814 Kongeriket Norges Grunnlov (Grunnloven) av 17.05.1814

1915 Lov om domstolene (domstolloven) av 13.08.1915 nr. 5

1981 Lov om barn og foreldre (barnelova) av 08.04.1981 nr. 7

1991 Lov om ekteskap (ekteskapsloven) av 04.07.1991 nr. 47

1997 Lov om familievernkontorer av 19.06.1997 nr. 62

1999 Lov om styrking av menneskerettighetenes stilling i norsk rett (menneskerettsloven) av 21.05.1999 nr. 30

2002 Lov om barnetrygd (barnetrygdloven) av 08.03.2002 nr. 4

2003 Lov om endringer i menneskerettsloven mv. (innarbeiding av barnekonvensjonen i norsk lov) av 01.08.2003 nr. 86

2005 Lov om mekling og rettergang i sivile tvister (tvisteloven) av 17.06.2005 nr. 90

2006 Forskrift om mekling etter ekteskapsloven og barneloven av 18.12.2006 nr. 1478

\section{Traktater}

Wien-konvensjonen Wien-konvensjonen om traktatretten, Wien 23.mai 1969

Barnekonvensjonen $\quad$ FNs konvensjon om barnets rettigheter av 20.november 1989

\section{FORARBEIDER}

Norges offentlige utredninger (NOU)

NOU 1977:35 Lov om barn og foreldre (barneloven)

NOU 1998:17 Barnefordelingssaker - avgjørelsesorgan, saksbehandlingsregler og delt bosted

\section{Proposisjoner til Odelstinget/Stortinget (Ot.prp./Prop. L)}

Ot.prp.nr. 62 (1979-1980) Om lov om barn og foreldre (barneloven)

Ot.prp.nr. 28 (1990-1991) Om lov om ekteskap

Ot.prp.nr. 29 (2002-2003) Om lov om endringer i barneloven mv. (Nye saksbehandlingsregler i barnefordelingssaker for domstolene $\mathrm{mv}$.)

Ot.prp.nr 45 (2002-2003) Om lov om endring i menneskerettsloven mv. (innarbeiding av 
barnekonvensjonen i norsk lov)

Ot.prp.nr 103 (2004-2005) Om lov om endringer i barnelova mv. (omfang av samvar, styrking av meklingsordningen, tiltak for å beskytte barn mot overgrep, foreldreansvar etter d $\phi d s f a l l$, tilbakebetaling av barnebidrag $m v$.)

Prop.85 L (2012-2013)Ｅndringer i barnelova (barneperspektivet i foreldretvister)

\section{Innstillinger til Odelstinget (Innst.O)}

Innst.O. nr. 71 (1990-1991) Innstilling fra justiskomiteen om lov om ekteskap

Innst.O. nr. 92 (2002-2003) Innstilling fra justiskomiteen om lov om endring i menneskerettsloven mv. (innarbeiding av barnekonvensjonen $i$ norsk lov).

\section{Stortingsmeldinger (St.meld.)}

St.meld.nr. 29 (2002-2003) Om familien-forpliktende samliv og foreldreskap

\section{ANDRE OFFENTLIGE DOKUMENTER}

\section{Rundskriv}

Rundskriv Q-02/2008 Forskrift om mekling etter ekteskapsloven og barneloven. Barne- og likestillingsdepartementet, 2008 http://www.regjeringen.no/nb/dep/bld/dok/rundskriv/2008/meklingetter-ekteskapsloven-og-barnelov.html?regj_oss=1\&id=504100 (sist lastet 05.11.2014)

\section{Veiledere og brosjyrer}

Veileder Q-15/2004 Om saksbehandlingsregler i barnefordelingssaker for domstolene og høring av barn. Barne- og familiedepartementet, mars 2004 http://www.regjeringen.no/nb/dep/bld/dok/veiledninger_brosjyrer/20 04/om-saksbehandlingsregler-ibarnefordelin.html?regj_oss=1\&id=88086 (sist lastet 05.11.2014)

Brosjyre Q-1069 Barn og samlivsbrudd. Barne- og likestillingsdepartementet, juli 2004

http://www.regjeringen.no/nb/dep/bld/dok/veiledninger_brosjyrer/20 04/barn-og-samlivsbrudd.html?id=88105 (sist lastet 05.11.2014) 
Brosjyre Q-1070 Hva med min mening da? Barne- og likestillingsdepartementet, juli 2004

http://www.regjeringen.no/nb/dep/bld/dok/veiledninger_brosjyrer/20 $\underline{\text { 04/hva-med-min-mening-da.html?id=88109 }}$ (sist lastet 05.11.2014)

Artikkelsamling Q- $\quad$ Samtaler med små barn i saker etter barneloven. Barne- og likestil1106 lingsdepartementet, mai 2006 http://www.regjeringen.no/nb/dep/bld/dok/veiledninger_brosjyrer/20 06/samtaler-med-sma-barn-i-saker-etter-barn.html?id=88466 (sist lastet 05.11.2014)

Brosjyre Q-0795 Mekling for foreldre. Barne- og likestillingsdepartementet, januar 2008

http://www.regjeringen.no/nb/dep/bld/dok/veiledninger_brosjyrer/20

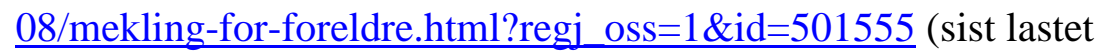
12.11.2014)

Veileder Q-1156

Snakk med meg! En veileder om å snakke med barn i barnevernet. Barne- og likestillingsdepartementet, juni 2009

http://www.regjeringen.no/nb/dep/bld/dok/veiledninger_brosjyrer/20 09/snakk-med-meg.html?id=577710 (sist lastet 12.11.2014)

\section{Annet}

BLD rapport (2011) Oppfølging av avsluttende merknader fra FNs barnekomité av januar 2010, Barne-, likestillings- og inkluderingsdepartementet, juni 2011 http://www.regjeringen.no/upload/BLD/Rapport_Barnekomiteens_m erknader.pdf (sist lastet 05.11.2014)

\section{INTERNASJONALE DOKUMENTER}

\section{FNs barnekomité}

General Comment No. 5 (2003) General measures of implementation of the Convention on the Rights of the Child (arts. 4, 42 and 44, para. 6) (CRC/GC/2003/5) http://daccess-ddsny.un.org/doc/UNDOC/GEN/G03/455/14/PDF/G034551 4.pdf?OpenElement (sist lastet 12.11.2014) 
General Comment No. 12 (2009) The right of the child to be heard (CRC/C/GC/12)

http://www2.ohchr.org/english/bodies/crc/docs/Advance Versions/CRC-C-GC-12.pdf (sist lastet 12.11.2014)

Concluding Observations (2010) Concluding observations: Norway (CRC/C/NOR/CO/4) http://www.regjeringen.no/nb/dokumentarkiv/stoltenberg -ii/bld/Tema-og-redaksjonelt-innhold/Redaksjonelleartikler/2010/concluding-observations-fra-fnsbarnekom.html?id=593247 (sist lastet 12.11.2014)

\section{Andre}

Manual on Human Rights Reporting: Under six major international human rights instruments 1997), Geneva, United Nations, 1997

http://www.hrea.org/erc/Library/display_doc.php?url=http\%3A\%2F\%2Fwww.ohchr.org\%2F Documents\%2FPublications\%2Fmanualhrren.pdf $+\&$ external=N (sist lastet 05.11.2014)

\section{DOMMER}
Rt. 1999 s. 1183
Rt. 2001 s. 1006
Rt. 2004 s. 811
Rt. 2005 s. 682
Rt. 2006 s. 929

\section{LITTERATUR}

\section{Bøker}

Andenæs, Mads Henry. Rettskildelare. 2.utg. Oslo, 2009

Boe, Erik Magnus. Rettskildelaere under debatt. Oslo, 2012

Eckhoff, Torstein. Rettskildelare. 5.utg. ved Jan E. Helgesen. Oslo, 2001

Ekeland, Tor-Johan. Skilte foreldre. Om samlivsbrot og foreldremekling. Oslo, 1994

Haugen, Gry Mette D. og Minna Rantalaiho. Barns rettigheter i mekling ved separasjon og samlivsbrudd. I: Anne Trine Kjørholt (red.), Barn som samfunnsborgere - til barnets beste? Oslo, 2010, s. 111-131

Haugli, Trude. Hensynet til barnets beste. I: N. Høstmælingen, E. S. Kjørholt, K. Sandberg (red.), Barnekonvensjonen. Barns rettigheter i Norge. 2.utg, Oslo, 2012, s. 51-72

Holgersen, Gudrun. Barnerett. Kristiansand, 2008 
Kjølberg, Gunn-Mari og Sigrid Redse Johansen. Barnefordelingstvister. Håndbok $i$ barnerettslige emner. Bergen, 2006

Nordhelle, Grethe. Mekling - for barnas skyld. I: Juridisk rådgivning for kvinner. Festskrift JURKs 25 års jubileum. Oslo, 1999, s. 45-54

Nordhelle, Grethe. Mekling. Konfliktforståelse og konflikthåndtering. 1.utg. Oslo, 2006

Nordhelle, Grethe. Mekling II. Sentrale temaer i konflikthåndtering. 1.utg. Oslo, 2007

Sandberg, Kirsten. Barns rett til å bli hørt. I: N. Høstmælingen, E. S. Kjørholt, K. Sandberg (red.) Barnekonvensjonen. Barns rettigheter i Norge, Oslo, 2008, s. 77-96

Sandberg, Kirsten. Barns rett til medbestemmelse - et juridisk perspektiv. I: Anne Trine Kjørholt (red.), Barn som samfunnsborgere - til barnets beste? Oslo, 2010, s. 47-70

Sandberg, Kirsten. Barns rett til å bli hørt. I: N. Høstmælingen, E. S. Kjørholt, K. Sandberg (red.) Barnekonvensjonen. Barns rettigheter i Norge. 2.utg. Oslo, 2012, s. 90-118

Skjørten, Kristin. Barns meninger om samvar. I: Anne Trine Kjørholt (red.), Barn som samfunnsborgere - til barnets beste? Oslo, 2010, s. 89-110

Smith, Lucy og Peter Lødrup. Barn og foreldre. 7.utg. Oslo, 2006

Smith, Lucy. FNs konvensjon om barnets rettigheter. I: N. Høstmælingen, E. S. Kjørholt, K. Sandberg (red.) Barnekonvensjonen. Barns rettigheter i Norge. 2.utg. Oslo, 2012, s. 17-30

Tjersland, Odd Arne. Samlivsbrudd og foreldreskap. Meklingsprosessens psykologi. Oslo, 1992

Øvreeide, Haldor. Samtaler med barn. Metodiske samtaler med barn i vanskelige livssituasjoner. 3.utg, Kristiansand, 2009

\section{Artikler}

Cashmore, Judy og Patrick Parkinson. Children's and parents' perceptions on children's participation in decision making after parental separation and divorce. I: Family Court Review, Vol. 46 No. 1, 2008, s. 91-104.

http://onlinelibrary.wiley.com/doi/10.1111/j.1744-1617.2007.00185.x/pdf (sist lastet 12.11.2014)

Galtung, Terje. Barnet og foreldrenes rettssak. I: NOU 1998:17, Vedlegg 4, s. 121-124

Gulbrandsen, Wenke og Odd Arne Tjersland. Mekling ved samlivsbrudd: en oversikt over effektstudier. I: Tidsskrift for norsk psykologforening. Årg. 47/8, 2010, s. 705-714

Langballe, Åse og Kari Trøften Gamst. En dialogisk tilnarming til kommunikasjon med barn. I: Artikkelsamling Q-1106, BLD, 2006, s. 34-47 (se link over) 
Rød, Oddny. Barns deltakelse i mekling og samvarssaker - Barnehфringsmodellen som metode. I: Fokus på familien 02/2010, s. 116-133 (Sitert fra Idunn.no)

Skjørten, Kristin. Foreldretvister - og фkt vektlegging av barns synspunkter. I: Tidsskrift for familierett, arverett og barnevernrettslige spørsmål (FAB), 2/2014, s. 79-81 (Sitert fra Rettsdata.no)

Smith, Lucy. Barnets beste og barnets uttalerett. I: Tidsskrift for familierett, arverett og barnevernrettslige spørsmål (FAB), nr. 3/4, 2004, s. 223-231 (Sitert fra Rettsdata.no)

Tjersland, Odd Arne og Wenke Gulbrandsen. Mekling ved samlivsbrudd: oversikt over modeller og ideologi. I: Tidsskrift for norsk psykologforening. Årg. 47/8, 2010, s. 692-700

Øvreeide, Haldor. Å samtale med barn om barnelovspфrsmål. I: Artikkelsamling Q-1106, BLD, 2006, s. 20-32 (se link over)

\section{Nettdokumenter}

Barneombudet. Barnas stemme stilner i stormen. En bedre prosess for barn som opplever samlivsbrudd. Rapport 2012. http://barneombudet.no/wpcontent/uploads/2013/09/Barnas_stemme_stilner_sept2014_02.pdf (sist lastet 13.11.2014)

Bufdir (Barne,- ungdoms- og familiedirektoratet). Arssrapport 2013 http://www.bufetat.no/Documents/Bufetat.no/Bufdir_A\%cc\%8arsrapport_web_enkeltsider.pd f (sist lastet 13.11.2014)

Bufetat (Barne-, ungdoms- og familieetaten). Presentasjonsbrosjyre familievernet http://www.bufetat.no/PageFiles/7920/Famv\%20pres\%20brosjyre\%20bokm\%c3\%a51.pdf (sist lastet 13.11.2014)

Ekeland, Tor Johan og Vidar Myklebust. Foreldremekling. Meklarperspektivet. Forskningsrapport nr. 12. Volda: Høgskulen i Volda, Møreforskning Volda, 1996 http://www.nb.no/nbsok/nb/dcd809570af8fd63f8ca37bbc6095f49.nbdigital?lang=no\#0 (sist lastet 12.11.2014)

Ekeland, Tor Johan og Vidar Myklebust. Foreldremekling. Brukarperspektivet. Forskningsrapport nr. 23. Volda: Høgskulen i Volda. Møreforskning i Volda. 1997 http://evalueringsportalen.no/evaluering/foreldremekling-brukarperspektivet (sist lastet 12.11.2014) 
Goldson, Jill. Hello, I'm a voice, let me talk. Child-Inclusive Mediation in Family Separation. Center for Child and Family Policy Research, New Zealand, 2006

http://www.familiescommission.org.nz/sites/default/files/downloads/IP-hello-im-a-voice.pdf (sist lastet 17.11.2014)

Søvig, Karl Harald. Barnets rettigheter på barnets premisser - utfordringer i møtet mellom FNs barnekonvensjon og norsk rett. Utredning for BLD, Bergen, 2009

http://www.regjeringen.no/upload/BLD/Barnets\%20rettigheter/Utredning_Sovig_end_versj.p

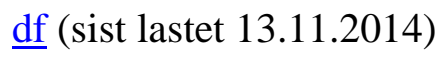

Ådnanes, Marian, Gry Mette D. Haugen, Heidi Jensberg, Minna Rantalaiho, Tonje Lossius Husum. Evaluering av mekling etter ekteskapslov og barnelov. Trondheim: SINTEF og NTNU, Rapport A20162, 2011

http://www.sintef.no/upload/Helse/Helsetjenesteforskning/A20162.pdf (sist lastet 13.11.2014)

\section{NETTSIDER}

«Den viktigste stemmen» 2014, Goal for Children

http://www.goalforchildren.no/Den-viktigste-stemmen/Se-landets-fremste-fagpersoner-paabarn-og-barnerett (sist lastet 17.11.2014)

SSB (2014): Mekling for foreldre, 2013, publisert 26.juni 2014

http://www.ssb.no/sosiale-forhold-og-kriminalitet/statistikker/meklingfam (lastet 13.11.2014) 